January 1999

\title{
Insider Trading Regulation: The Path Dependent Choice between Property Rights and Securities Fraud
}

Stephen M. Bainbridge

\section{Recommended Citation}

Stephen M. Bainbridge, Insider Trading Regulation: The Path Dependent Choice between Property Rights and Securities Fraud, 52 SMU L. Rev. 1589 (1999)

https://scholar.smu.edu/smulr/vol52/iss4/8

This Article is brought to you for free and open access by the Law Journals at SMU Scholar. It has been accepted for inclusion in SMU Law Review by an authorized administrator of SMU Scholar. For more information, please visit http://digitalrepository.smu.edu. 


\title{
Insider Trading Regulation: The Path Dependent Choice Between PROPERTY RightS AND Securities Fraud
}

\author{
Stephen M. Bainbridge*
}

\section{INTRODUCTION}

$\mathrm{T}$

THE modern federal insider trading prohibition is, at least according to Congress and the Securities and Exchange Commission (SEC), one of the central pillars and proudest accomplishments of American securities law. ${ }^{1}$ Unfortunately, it is also an instructive case study in how a legal regime exhibiting path dependent features went awry, detaching itself from both statutory and policy moorings. Of particular interest is the Supreme Court's most recent insider trading decision United States v. O'Hagan, ${ }^{2}$ wherein the court upheld the so-called "misappropriation theory" of insider trading liability, but took an area in which the law made a certain amount of policy sense, albeit at the cost of substantial doctrinal tensions, and made a hash of it.

In economics, path dependence is one of the concepts that reconciles market failures with rational choice theory. ${ }^{3}$ The popular caricature of neo-classical economics has something of a Social Darwinist flavor. Economic evolution tends to favor efficient equilibria, or so the story goes, while inefficient local equilibria tend to become extinct. Path dependence, in contrast, claims that inefficient local equilibria can persist over time. Initial conditions, which may be determined by chance or other non-economic forces (such as political interests), direct the system down a particular path. Subsequent deviations from that path may be precluded as too costly, even if there are more desirable or efficient alternatives available. ${ }^{4}$ Where the cost of reversing the initially chosen starting point is especially high, an inefficient equilibrium that resists correction

* Professor, UCLA School of Law. Thanks to Mitu Gulati and Bill Klein for comments on an earlier draft.

1. See, e.g., H.R. REP. No. 98-355, at 1 (1984) (condemning insider trading and praising efforts to deter it).

2. 521 U.S. 642,650 (1997).

3. See generally S. J. Liebowitz \& Stephen E. Margolis, Path Dependence, Lock-In, and History, 11 J. L. EcoN. \& ORG. 205 (1995).

4. See Ronald J. Gilson, Corporate Governance and Economic Efficiency: When Do Institutions Matter?, 74 WASH. U. L.Q. 327, 329-30 (1996). 
by market forces may result.$^{5}$

Some legal regimes exhibit characteristics of path dependent systems. Such a regime is politically and historically contingent, an artifact of initial conditions and its path dependent evolution. For example, regulation of a certain type of behavior may be arbitrarily assigned to a particular agency. In retrospect, as the legal regime evolves, we may recognize that the initial assignment of regulatory responsibility was unfortunate. Perhaps the legal regime has evolved such that the issues are no longer within the agency's technical expertise. Alternatively, the regime may have evolved such that the issue is no longer within the agency's legal jurisdiction. In either case, the costs of reassigning the legal regime to a more appropriate regulatory body may be sufficiently high to justify permitting the initial agency to retain jurisdiction. In order to prevent the legal equivalent of a market failure, however, we may need to adjust the agency's regulatory purview or overlook various doctrinal irregularities.

To be clear from the outset, I do not claim that the federal insider trading prohibition is a path dependent legal regime. I claim only that path dependence provides a pedagogically useful metaphor, in that it focuses our attention on those aspects of the prohibition's evolution that led it astray. Accordingly, I am using path dependence in a more colloquial sense than the economists embroiled in the debate over the theory's validity would regard as appropriate. I do so because it is path dependence as the term is used colloquially-a historically contingent starting point and a high cost associated with changing paths-that provides the hermeneutically useful metaphor.

The SEC initially captured regulatory authority over insider trading in the 1960s. Insider trading has been treated as a species of securities fraud ever since. Yet, there was nothing inevitable about this initial starting point. Early common law essentially treated insider trading as a state corporate law problem, implicating the fiduciary duties of officers and directors. With the benefit of hindsight we might not have chosen an initial starting point that put us on the securities fraud path. As the prohibition has evolved, the federal securities laws have become an increasingly poor fit within which to confine insider trading.

Since the Supreme Court's decision in United States v. Chiarella, ${ }^{6}$ insider trading liability has been based on a breach of fiduciary duty. In order for liability to arise under the traditional disclose or abstain standard, the inside trader must have breached a duty owed to the person

5. The claim for path dependence is that a minor or fleeting advantage or a seemingly inconsequential lead for some technology, product, or standard can have important and irreversible influences on the ultimate market allocation of resources, even in a world characterized by voluntary decisions and individually maximizing behavior .... [Path dependence thus] means that marginal adjustments of individual agents may not offer the assurance of optimization or the revision of suboptimal outcomes.

Liebowitz \& Margolis, supra note 3, at 205-06.

6. 445 U.S. 222 (1980). 
with whom he/she traded. ${ }^{7}$ Under the misappropriation theory, it suffices that the inside trader breached a duty owed to the source of the information. ${ }^{8}$ O'Hagan, a partner in the law firm representing the prospective bidder in a pending takeover, owed no duties to the persons with whom he traded, but did owe duties of loyalty and confidentiality to his client. ${ }^{9}$ Hence, O'Hagan could be held liable, if at all, only under the misappropriation theory.

The pre-O'Hagan misappropriation theory made substantial economic sense. The insider trading prohibition ought to be viewed as a means of protecting property rights in information, rather than as a means of preventing securities fraud. Viewed from that perspective, the preO'Hagan misappropriation theory correctly imposed liability on those who converted information that belonged to another for their own personal profit. Unfortunately, the SEC's regulatory jurisdiction over insider trading meant that the problem was treated as a species of securities fraud rather than one of property rights. As a result, the insider trading prohibition inherently suffered from a number of significant tensions at both the doctrinal and policy levels.

Nevertheless, we have come an awfully long way down this particular path. Reversing course by divesting the SEC of regulatory jurisdiction over insider trading, as some have proposed, would be quite costly. Not only is there now a well-developed body of insider trading regulation under the federal securities laws, but the SEC also has a demonstrable comparative advantage in detecting and prosecuting insider trading. More subtle costs relating to issues of statutory interpretation and federalism will become apparent as we delve deeper into the problem. Upon close evaluation, the path dependence metaphor counsels tinkering with the prohibition, but not sweeping change.

Part II of this Article outlines the path dependence metaphor as I intend to apply it here. Part III then uses the metaphor as a vehicle for exploring the evolution of the insider trading prohibition from its origins in the equal access test announced in the Second Circuit's seminal Texas Gulf Sulphur ${ }^{10}$ decision, to the Supreme Court's decisions in Chiarella and Dirks, ${ }^{11}$ through the subsequent lower court decisions that created the misappropriation theory.

Part IV turns to a critique of the Supreme Court's recent O'Hagan decision. As we shall see, the Court ducked, misunderstood, or mishandled virtually every issue presented by that case. O'Hagan nevertheless rewards careful analysis in several respects. First, $O^{\prime}$ Hagan sheds light on the proper understanding and interpretation of Supreme Court decisionmaking in highly technical statutory cases. Specifically, I propose that

7. See id. at $226-30$.

8. See O'Hagan, 521 U.S. at 652.

9. See id. at 653 . (1968).

10. SEC v. Texas Gulf Sulphur, 401 F.2d 833 (2d Cir. 1968), cert. Denied 394 U.S. 976

11. Dirks v. SEC, 463 U.S. 646 (1983). 
Supreme Court decisionmaking in such areas is compromised by bounded rationality and, accordingly, by a tendency to give undue deference to specialists. Although further research will be necessary to fully develop this thesis, the present account is highly suggestive. In particular, it explains the otherwise puzzling acquiescence of courts in the SEC's program of expanding the insider trading prohibition. Second, O'Hagan has important, albeit uncertain, implications for Rule $10 \mathrm{~b}-5$ jurisprudence. In particular, precedents touching on federalism and statutory interpretation in this context have been left suspect, if not actually rendered nugatory. Finally, O'Hagan has some surprising implications for the role property and contracts play in determining the scope of securities fraud claims. It is widely assumed that the federal securities laws are mandatory, not enabling. ${ }^{2}$ Parties presumably cannot opt out of those rules by contract or otherwise. Yet, the logic of $O^{\prime}$ Hagan implicitly validates opting out of the securities laws or, at least, of Rule 10b-5. Part IV concludes by returning to the core intuition of this Article, that insider trading ought to be regarded as a property rights problem rather than a securities fraud issue, but that the prohibition's path dependent evolution suggests the need for doctrinal compromise in order to resolve the resulting tensions. Unfortunately, the $O^{\prime} H a g a n$ majority muffed the opportunity to craft just such a compromise.

\section{METAPHOR}

I do not intend to claim that the federal insider trading prohibition meets the economic criteria of a path dependent system. Nor do I intend to take a position on the debatable question of whether path dependency is an economically significant phenomenon in the real world, ${ }^{13}$ and, if so, whether a theory that may explain the persistence of suboptimal products translates into a theory that demonstrates the existence and persistence of suboptimal legal rules. ${ }^{14}$ My claim is only that in this particular context, path dependency is a pedagogically useful metaphor.

Mark Roe offers a nice parable, which neatly captures the core intuition of the metaphor as I propose to use it:

We are on a road and wonder why it winds and goes here instead of there, when a straight road would be a much easier drive. Today's road depends on what path was taken before. Decacles ago, a fur trader cut a path through the woods, and the trader, bent on avoiding a wolves' den and other dangerous sites, took a winding indirect route. Were the fur trader a better hunter of wolves, the trader

12. See, e.g., Roberta Romano, The Genius of American Corporate Law 91 (1993).

13. Liebowitz \& Margolis, supra note 3, persuasively demonstrate that stable inefficient equilibria ascribable to path dependence are both theoretically improbable and empirically rare.

14. For an excellent discussion of this issue, which also provides a useful overview of the legal literature on the path dependence phenomenon, see Frederick W. Lambert, Path Dependent Inefficiency in the Corporate Contract: The Uncertain Case with Less Certain Implications, 23 DEL. J. CORP. L. 1077 (1998). 
might have chosen a straighter path. Later travelers dragged wagons along the same winding path the trader chose, deepening the grooves and clearing away some trees. Travelers continued to deepen and broaden the road even after the dangerous sites were gone. Industry came and settled in the road's bends; housing developments went up that fit the road and industry. Local civic promoters widened the path and paved it into a road suitable for today's trucks. It is time to resurface the road. Should today's authorities straighten it out at the same time? ${ }^{15}$

In this road parable, as I shall refer to it hereinafter, the highway's course was determined by a historically contingent set of initial starting conditions: namely, the trader's need to avoid danger. Small changes in that initial set of conditions might have led to an outcome that would be more desirable today; namely, a straight road. Because the costs of straightening the road appear excessive, however, we are now stuck in a local equilibrium that preserves the winding road.

Roe implies that the winding road is (or, at least, may be) inefficient, ${ }^{16}$ but I am not so sure. The road parable, as he set it up, is an example of what economists Stan Leibowitz and Stephen Margolis call "second-degree path dependence." 17 This form of path dependence involves socalled regrettable choices. Decisions made with imperfect ex ante knowledge may result in an outcome that ex post is undesirable but also would be costly to change. If the ultimate inferiority of the decision could not have been known at the initial starting point and the costs of changing paths exceed the benefits of such a change the resulting local equilibrium technically is not inefficient.

A local equilibrium is inefficient in the Pareto superiority sense if it is possible to make at least one person better off without making anyone worse off. In terms of Roe's parable, a winding road is inefficient in this sense only if someone will gain from straightening the road and no one will be injured. As Roe has set up the problem, however, it is clear that some persons, such as the owners of the factories along the roadside, will incur significant costs if the road's course is changed. Even if we switch gears to Kaldor-Hicks efficiency, the winding road still may not be inefficient. A change in position is Kaldor-Hicks efficient even if some persons are worse off, so long as the gains to those who are better off are sufficient to compensate the losers. To say that the winding road is inefficient in the Kaldor-Hicks sense is to assert that the benefits of straightening the road exceed the costs of doing so, including the costs incurred by those persons who have adapted to the road's current course. It is not at all clear that the winding road, as Roe has set up the problem, is inefficient in this sense. It could well be that the gains to those who are better off with a straight road are insufficient to compensate those who will lose

15. Mark J. Roe, Chaos and Evolution in Law and Economics, 109 HARV. L. Rev. 641, 643 (1996).

16. See id. at 644.

17. Liebowitz \& Margolis, supra note 3, at 207. 
in the straightening process. ${ }^{18}$

The distinction between the second-degree path dependence exhibited by the road parable and true (or third-degree) path dependence is driven by the availability of a feasible alternative to the suboptimal equilibrium. Only if such an alternative is available does the phenomenon in question demonstrate true path dependence. Only if such an alternative nevertheless remains untaken can the phenomenon in question even potentially be deemed inefficient in either the Pareto superior or Kaldor-Hicks sense.

\section{EVOLUTION}

As applied to the insider trading problem, the path dependence metaphor focuses our attention on what I believe to be the critical issues: Was the choice of securities fraud as the vehicle for regulating insider trading historically contingent or was it mandated by efficiency considerations? As the prohibition evolved, did that choice prove regrettable? If so, is the current equilibrium an inefficient one? What are the costs and benefits of straightening the path we have been following for the last thirtyplus years?

\section{A. The Securities Fraud Path}

The modern federal insider trading prohibition fairly can be said to have begun with the SEC's enforcement action In re Cady, Roberts \& Co. ${ }^{19}$ Curtiss-Wright Corporation's board of directors decided to reduce the company's quarterly dividend. One of the directors, J. Cheever Cowdin, was also a partner of Cady, Roberts \& Co., a stock brokerage firm. Before the news was announced, Cowdin informed one of his partners, Robert M. Gintel, of the impending dividend cut. Gintel then sold several thousand shares of Curtiss-Wright stock held in customer accounts over which he had discretionary trading authority. When the dividend cut was announced, Curtiss-Wright's stock price fell several dollars per share. Gintel's customers thus avoided substantial losses.

Cady, Roberts involved what is now known as "tipping:" an insider who knows confidential information does not himself trade, but rather informs, tips, someone else, who does trade. It also involved trading on an impersonal stock exchange, instead of a face-to-face transaction. As the

18. Admittedly, I am assuming away other forms of market failure, such as free-riding, collective action problems, and interest group interference in the political process. As Roe correctly points out, in the presence of one or more such market failures, an inefficient local equilibrium might be preserved despite the evolutionary workings of market forces. See Roe, supra note 15, at 651 (Roe calls this "strong-form path dependence"). In such a case, however, it is incorrect to blame the resulting inefficiency on either the initially chosen starting point or the path dependent nature of its evolution. Instead, any present inefficiency is correctly blamed on the specific market failure that prevents us from making a Kaldor-Hicks efficient change. Roe acknowledges the point. See id. at 652 n.21.

19. 40 S.E.C. 907 (1961). 
SEC acknowledged, this made it "a case of first impression."20 Although Rule 10b-5 had sometimes been invoked prior to Cady, Roberts to deal with insider trading-like issues, those cases typically involved issues of tortious fraudulent concealment in face-to-face or control transactions. ${ }^{21}$ Notwithstanding, the SEC held that Gintel had violated Rule 10b-5. In so doing, it articulated what became known as the "disclose or abstain" rule: An insider in possession of material nonpublic information must disclose such information before trading or, if disclosure is impossible or improper, abstain from trading. ${ }^{22}$

It was not immediately clear what precedential value Cady, Roberts would have. ${ }^{23}$ It was an administrative ruling by the SEC, not a judicial opinion. It involved a regulated industry, closely supervised by the SEC. Neither the text of the statute nor its legislative history supported, let alone mandated, a broad insider trading prohibition. ${ }^{24}$ There was a long line of state law precedent to the contrary. ${ }^{25}$ In short order, however, Cady, Roberts became the law of the land.

If Cady, Roberts was a regulatory power-grab by the SEC, the Second Circuit vindicated and validated the Commission's action in SEC v. Texas Gulf Sulphur Co. ${ }^{26}$ In March 1959, agents of Texas Gulf Sulphur Co. (Texas Gulf Sulphur), a mining corporation, began aerial surveys of an area near Timmins, Ontario. They found evidence of an ore deposit. In October 1963, Texas Gulf Sulphur began ground surveys of the area. In early November, a drilling rig took core samples from depths of several hundred feet. Visual examination of the samples suggested commercially significant deposits of copper and zinc. Texas Gulf Sulphur's president ordered the exploration group to maintain strict confidentiality, even to the point of withholding the news from other Texas Gulf Sulphur direc-

20. Id. at 907.

21. The handful of Rule $10 \mathrm{~b}-5$ decisions cited as precedent by Cady, Roberts uniformly involved face-to-face transactions and/or control transactions. See, e.g., Speed v. Transamerica Corp., 99 F. Supp. 808 (D. Del. 1951) (omissions in connection with what amounted to a tender offer); Kardon v. Nat'l Gypsum Co., 73 F. Supp. 798 (E.D. Pa. 1947) (sale of control negotiated face to face); In re Ward La France Truck Corp., 13 S.E.C. 373 (1943) (same). As such, they do not support extension of Rule 10b-5 or Section 10(b) to modern insider trading violations on impersonal stock exchanges. Interestingly, in a postCady, Roberts case (but pre-Texas Gulf Sulphur), arising under Rule 10b-5, the Seventh Circuit applied the old state law special circumstances rule to a face-to-face transaction, which confirms that there was no general bar on insider trading prior to Texas Gulf Sulphur. See Kohler v. Kohler Co., 319 F.2d 634, 638 (7th Cir. 1963).

22. See Cady, Roberts, 40 S.E.C. at 911.

23. See, e.g., Recent Decisions, 48 VA. L. REv. 398, 403-04 (1962) ("[I]n view of the limited resources of the Commission, the unfortunate existence of more positive and reprehensible forms of fraud, and the inherent problems concerning proof and evidence adhering to any controversy involving a breach of duty of disclosure, there is little prospect of excessive litigation evolving pursuant to [Cady, Roberts]").

24. Although the claim is somewhat controversial, I have argued elsewhere that Congress in 1934 did not intend for Section 10(b) to prohibit insider trading as we know it today. See Stephen M. Bainbridge, Incorporating State Law Fiduciary Duties into the Federal Insider Trading Prohibition, 52 WASH. \& LEE L. REv. 1189, 1228-34 (1995) [hereinafter Bainbridge, State Law].

25. See id. at 1218-27 (analyzing cases).

26. See Texas Gulf Sulphur, 401 F.2d at 833. 
tors and employees. In early December, a chemical assay confirmed the presence of copper, zinc, and silver. At the subsequent trial, several expert witnesses testified that they had never heard of any other initial exploratory drill hole showing comparable results. Over the next several months, Texas Gulf Sulphur acquired the rights to the land under which this remarkable ore deposit lay. In March and early April 1964, further drilling confirmed that Texas Gulf Sulphur had made a significant ore discovery. After denying several rumors about the find, Texas Gulf Sulphur finally announced its discovery in a press conference on April 16, 1964.

Throughout the fall of 1963 and spring of 1964, a number of Texas Gulf Sulphur insiders bought stock and/or options on company stock. Others tipped off outsiders, while others accepted stock options from the company's board of directors without informing the directors of the discovery. Between November 1963 and March 1964, the insiders were able to buy at prices that were slowly rising, albeit with fluctuations, from just under $\$ 18$ per share to $\$ 25$ per share. As rumors began circulating in late March and early April, the price jumped to about $\$ 30$ per share. On April 16th, the stock opened at $\$ 31$, but quickly jumped to $\$ 37$ per share. By May 15,1964 , Texas Gulf Sulphur's stock was trading at over $\$ 58$ per share-a $222 \%$ rise over the previous November's price. ${ }^{27}$ Any joy the insiders may have taken from their profits was short-lived, however, as the SEC sued them for violating Rule $10 \mathrm{~b}-5$.

In what quickly became a leading opinion, the Second Circuit agreed with the SEC that rule $10 \mathrm{~b}-5$ had been violated. The court held that when an insider has material nonpublic information the insider must either disclose such information before trading or abstain from trading until the information has been disclosed. ${ }^{28}$ Thus, was born what is now known as the "disclose or abstain" rule.

Texas Gulf Sulphur thus started the insider trading prohibition down a path upon which insider trading was deemed a form of securities fraud and, accordingly, within the SEC's regulatory jurisdiction. There was nothing inevitable about that choice, however. State corporate law had been regulating insider trading for decades before Texas Gulf Sulphur was decided. Well-established state precedents treated the problem as one implicating not concepts of deceit or manipulation, but rather the fiduciary duties of corporate officers and directors. ${ }^{29}$ To be sure, many states held that insider trading did not violate those duties, especially with respect to stock market transactions, but so what? In light of those precedents, the Second Circuit could have held that insider trading was not within Rule 10b-5's regulatory purview. If it had done so, the prohibition

27. See id. at 843-47.

28. See id. at 848 .

29. See generally Bainbridge, State Law, supra note 24, at 1218-27 (overview of state common law). 
would have evolved along a far different path than the one it actually followed.

Although the starting point chosen for the prohibition's evolutionary path was historically contingent, it was likely far from accidental. ${ }^{30}$ The SEC had strong incentives to capture jurisdiction over insider trading. ${ }^{31}$ The Commission presumably desired to enlarge its jurisdiction and enhance its prestige. According to a widely accepted theory of bureaucratic behavior, administrators can maximize their salaries, power, and reputation by maximizing the size of their agency's budget. ${ }^{32}$ A vigorous enforcement program directed at a highly visible and unpopular law violation surely was an effective means of attracting political support for larger budgets. Given the media attention directed towards insider trading prosecutions, and the public taste for prohibiting insider trading, it provided a very attractive subject for such a program.

During the prohibition's formative years, there was a major effort to federalize corporate law. In order to maintain its budgetary priority over competing agencies, the SEC wanted to play a major role in federalizing matters previously within the state domain. Insider trading was an ideal target for federalization. Rapid expansion of the federal insider trading prohibition purportedly demonstrated the superiority of federal securities law over state corporate law. Because the states had shown little interest in insider trading for years, federal regulation demonstrated the modernity, flexibility, and innovativeness of the securities laws. The SEC's prominent role in attacking insider trading thus placed it in the vanguard of the movement to federalize corporate law and ensured that the Commission would have a leading role in any system of federal corporations law.

\section{B. The Road Curves}

The policy foundation on which the Second Circuit erected the disclose or abstain rule was equality of access to information. The court concluded (on the basis of two law review articles) that the federal insider trading prohibition was intended to assure that "all investors trading on impersonal exchanges have relatively equal access to material information." 33 Put another way, Congress purportedly intended "that all mem-

30. One of several reasons I find the road parable pedagogically useful in this context is that it immediately suggests the relevance of public choice analysis. Anyone even vaguely aware of how transportation policy gets made will recognize that the parable implies the need for and utility of an interest group-based mode of analysis.

31. I have elsewhere offered a more elaborate account of the SEC's incentives to capture and maintain its control of regulatory jurisdiction over insider trading, from which the following summary is drawn. See Bainbridge, State Law, supra note 24, at 1246-49. My account there drew, inter alia, on Michael P. Dooley, Enforcement of Insider Trading Restrictions, 66 VA. L. Rev. 1, 59-62 (1980) [hereinafter Dooley, Enforcement of Insider Trading].

32. See Glen O. Robinson, American Bureaucracy: Public Choice and PubLIC LAW 85 (1991).

33. Texas Gulf Sulphur, 401 F.2d at 848. 
bers of the investing public should be subject to identical market risks. . .."34

The equality of access principle admittedly has some intuitive appeal. As we shall see, the SEC consistently has tried to maintain it as the basis of insider trading liability. Many commentators still endorse it, typically on fairness grounds. ${ }^{35}$ The implications of the equal access principle become troubling when we start dealing with attenuated circumstances; especially with respect to market information. For example, suppose a Texas Gulf Sulphur representative had approached a landowner in the Timmins area to negotiate purchasing mineral rights to the land. Texas Gulf Sulphur's agent did not disclose the ore strike, but the landowner turns out to be pretty smart. She knows Texas Gulf Sulphur has been drilling in the area and has heard rumors that it has been buying up a lot of mineral rights. She puts two and two together, reaches the obvious conclusion, and buys some Texas Gulf Sulphur stock. Under a literal reading of Texas Gulf Sulphur, is our landowner liable for illegal insider trading?

The surprising answer is "probably." The Texas Gulf Sulphur court stated that the insider trading prohibition applies to "anyone in possession of material inside information," because Section 10(b) was intended to assure that "all investors trading on impersonal exchanges have relatively equal access to material information." 36 The court further stated that the prohibition applies to anyone who has "access, directly or indirectly" to confidential information if she knows that the information is unavailable to the investing public. ${ }^{37}$ The only issue thus may be a factual one, turning on the landowner's state of mind: whether she knew that she was dealing with confidential information. If so, the equal access policy would seem to justify imposing a duty on her. Query, however, whether the insider trading prohibition should stretch quite that far?

In Chiarella v. United States, ${ }^{38}$ the Supreme Court concluded that it should not. Unfortunately, as we shall see, the method by which it constrained the insider trading prohibition proved an infelicitous choice.

Vincent Chiarella was an employee of Pandick Press, a financial printer that prepared tender offer disclosure materials, among other documents. In preparing those materials, Pandick used codes to conceal the names of the companies involved, but Chiarella broke the codes. He purchased target company shares before the bid was announced, then sold the shares for considerable profits after announcement of the bid. He got

34. Id. at 852 .

35. See, e.g., Donald C. Langevoort, Words From on High About Rule 10b-5: Chiarella's History, Central Bank's Future, 20 DEL. J. CoRP. L. 865, 883 (1995) (expressing a preference for an insider trading prohibition grounded on a duty to disclose to the market).

36. Texas Gulf Sulphur, 401 F.2d at 848.

37. Id. (emphasis added).

38. 445 U.S. 222 (1980). 
caught and was indicted for illegal insider trading. ${ }^{39}$

Chiarella was convicted of violating Rule $10 \mathrm{~b}-5$ by trading on the basis of material nonpublic information. The Second Circuit affirmed his conviction, applying the same equality of access to information-based disclose or abstain rule it had created in Texas Gulf Sulphur. ${ }^{40}$ Under the equal access-based standard, Chiarella clearly loses: he had greater access to information than those with whom he traded.

The Supreme Court reversed. In doing so, the Court squarely rejected the notion that Section 10(b) was intended to assure all investors equal access to information. The Court said it could not affirm Chiarella's conviction without recognizing a general duty between all participants in market transactions to forego trades based on material, nonpublic information, and it refused to impose such a duty. ${ }^{41}$

Thus, Chiarella made clear that the disclose or abstain rule is not triggered merely because the trader possesses material nonpublic information. When a Rule $10 \mathrm{~b}-5$ action is based upon nondisclosure, there can be no fraud absent a duty to speak, and no such duty arises from the mere possession of nonpublic information. ${ }^{42}$ Instead, the disclose or abstain theory of liability for insider trading is premised on the inside trader being subject to a duty to disclose to the party on the other side of the transaction that arose from a relationship of trust and confidence between the parties. ${ }^{43}$ As applied to the facts at bar, Chiarella was not an employee, officer, or director of any of the companies in whose stock he traded. He worked solely for Pandick Press, which was not an agent of any of those companies. Pandick worked primarily for acquiring companies-not the takeover targets in whose stock Chiarella traded. Therefore he had no duty to disclose to those with whom he traded. ${ }^{44}$

Chiarella radically limited the scope of the insider trading prohibition as it had been defined in Texas Gulf Sulphur. Just three years later, however, the Supreme Court reaffirmed and refined its new approach to insider trading in Dirks $v$. SEC.45 Raymond Dirks was a securities analyst who uncovered the massive Equity Funding of America fraud. Dirks first began investigating Equity Funding after receiving allegations from Ronald Secrist, a former officer of Equity Funding, that the corporation was engaged in widespread fraudulent corporate practices. Dirks passed the results of his investigation to the SEC and the Wall Street Journal, but also discussed his findings with various clients. A number of those clients sold their holdings of Equity Funding securities before any public disclosure of the fraud, thereby avoiding substantial losses. After the fraud was made public and Equity Funding went into receivership, the SEC began

\footnotetext{
39. See id. at 224-25.

40. See id. at 232.

41. See id. at 233.

42. See id. at 235.

43. See id. at 230.

44. See id. at 232-33.

45. 463 U.S. 646 (1983).
} 
an investigation of Dirks's role in exposing the fraud, concluding that Dirks violated the federal insider trading prohibition by repeating the allegations of fraud to his clients. ${ }^{46}$

Under the Texas Gulf Sulphur equal access to information standard, tipping of the sort at issue in Dirks presented no conceptual problems. The tippee had access to information unavailable to those with whom he traded and, as such, was liable. After Chiarella, however, the tipping problem was more complex. Neither Dirks nor his customers were agents, officers, or directors of Equity Funding. Nor did they have any other form of special relationship of trust and confidence with those with whom they traded. They were complete strangers.

In reversing Dirks's censure, the Supreme Court reaffirmed its rejection of the equal access standard:

We were explicit in Chiarella in saying that there can be no duty to disclose where the person who has traded on inside information "was not [the corporation's] agent, ... was not a fiduciary, [or] was not a person in whom the sellers [of the securities] had placed their trust and confidence." Not to require such a fiduciary relationship, we recognized, would "depar[t] radically from the established doctrine that duty arises from a specific relationship between two parties" and would amount to "recognizing a general duty between all participants in market transactions to forgo actions based on material, nonpublic information." 47

Recognizing that the Chiarella formulation posed problems for tipping cases, the court held that tipping could violate the insider trading prohibition, but further held that a tippee's liability is derivative of the tipper's, "arising from his role as a participant after the fact in the insider's breach of a fiduciary duty." 48 A tippee, therefore, is held liable only when the tipper breaches a fiduciary duty by disclosing information to the tippee, and the tippee knows or has reason to know of the breach of duty. ${ }^{49}$

On the Dirks facts, this formulation precluded imposition of liability. To be sure, Secrist was an officer and, hence, a fiduciary of Equity Funding. But the mere fact that an insider tips nonpublic information is not enough under Dirks. What Dirks proscribes is not merely a breach of confidentiality by the insider, but rather a breach of the duty of loyalty imposed on all fiduciaries to avoid personally profiting from information entrusted to them..$^{50}$ Looking at objective criteria, courts must determine whether the insider personally benefited, directly or indirectly, from his disclosure. ${ }^{51}$ Secrist tipped off Dirks in order to bring Equity Funding's misconduct to light, not for any personal gain. Absent the requisite per-

46. See id. at 648-52.

47. Id, at 654-55 (citations omitted) (quoting Chiarella, 445 U.S. at 232-33).

48. Id. at 659 (quoting Chiarella, 445 U.S. at 230 n.12).

49. See id. at 660 .

50. See id. at 662 .

51. See id. 
sonal benefit, liability could not be imposed. ${ }^{52}$

Just as there had been nothing historically or economically inevitable about Texas Gulf Sulphur's imposition of the equal access standard, there was equally nothing inevitable about the Supreme Court's rejection of that standard. The equal access standard was consistent with a trend towards affirmative disclosure obligations and away from caveat emptor that was sweeping a broad swath across the common law. ${ }^{53}$ In rejecting this trend, Justice Powell arguably shifted the focus of insider trading liability from deceit to agency, a point that becomes especially significant later in our analysis. ${ }^{54}$ Nothing in the text of the statute or the rule explicitly mandated this shift, nor was it required by the relevant precedents. To the contrary, Justice Powell's use of precedent in Chiarella and Dirks was highly suspect.55 In Dirks, for example, he opined:

In the seminal case of In re Cady, Roberts \& Co., the SEC recognized that the common law in some jurisdictions imposes on "corporate 'insiders,' particularly officers, directors, or controlling shareholders" an "affirmative duty of disclosure ... when dealing in securities." The SEC found that ... breach of this common-law duty also establish[ed] the elements of a Rule $10 \mathrm{~b}-5$ violation. . . .56

Although Powell acknowledged that the common law duty upon which Cady, Roberts purportedly rested existed only in "some jurisdictions," he failed to acknowledge that that duty was essentially limited to face-toface transactions between the issuer's officers or directors and the issuer's current shareholders. With no analysis or citation of authority, moreover, Powell extrapolated from this limited, state common law duty the all-encompassing federal rule that all "insiders [are] forbidden by their fiduciary relationship from personally using undisclosed corporate information to their advantage. . .."57

\section{The Road Curves Back}

In response to the set-backs it suffered in Chiarella and Dirks, the SEC began advocating a new theory of insider trading liability: the misappropriation theory. The theory's origins are commonly (but incorrectly) traced to Chief Justice Burger's Chiarella dissent. Burger contended that the way in which the inside trader acquires the nonpublic information on which he trades could itself be a material circumstance that must be disclosed to the market before trading. Accordingly, he argued, "a person who has misappropriated nonpublic information has an absolute duty [to the persons with whom he trades] to disclose that information or to re-

52. See id. at 666-67.

53. See Langevoort, supra note 35 , at $870-71$.

54. See A.C. Pritchard, United States v. O'Hagan: Agency Law and Justice Powell's Legacy for the Law of Insider Trading, 78 B.U. L. Rev. 13, 15 (1998).

55. See Langevoort, supra note 35, at 872; Pritchard, supra note 54, at 22-29.

56. Dirks, 463 U.S. at 653 (citations omitted) (quoting In re Cady, Roberts \& Co., 40 S.E.C. 907,911 n.13 (1961)).

57. Id. at 659 . 
frain from trading." 58 The majority did not address the merits of this theory; instead the majority rejected the theory solely on the ground that it had not been presented to the jury, and thus could not sustain a criminal conviction..$^{59}$

Thus, the way was left open for the SEC to urge, and the lower courts to adopt, the misappropriation theory as an alternative basis of insider trading liability. The Second Circuit swiftly moved to take advantage of that opportunity. In United States $v$. Newman, ${ }^{60}$ employees of an investment bank misappropriated confidential information concerning proposed mergers involving clients of the firm. As was true of Vincent Chiarella, the Newman defendants' employer worked for prospective acquiring companies, while the trading took place in target company securities. As such, the Newman defendants owed no fiduciary duties to the investors with whom they traded. Moreover, neither the investment bank nor its clients traded in the target companies' shares contemporaneously with the defendants.

Unlike Chief Justice Burger's Chiarella dissent, the Second Circuit did not assert that the Newman defendants owed any duty of disclosure to the investors with whom they traded or had defrauded. Instead, the court held that by misappropriating confidential information for personal gain, the defendants had defrauded their employer and its clients, and this fraud sufficed to impose insider trading liability on the defendants with whom they traded ${ }^{61}$ As eventually refined, the (pre-O'Hagan) misappropriation theory thus imposed liability on anyone who: (1) misappropriated material nonpublic information; (2) thereby breaching a fiduciary duty or a duty arising out of a similar relationship of trust and confidence; and (3) used that information in a securities transaction, regardless of whether he owed any duties to the shareholders of the company in whose stock he traded. 62

Like the traditional disclose or abstain rule, the pre-O'Hagan misappropriation theory thus required a breach of fiduciary duty before trading on inside information became unlawful. ${ }^{63}$ The fiduciary relationship in question, however, was a quite different one. Under the misappropriation theory, the defendant did not need to owe a fiduciary duty to the investor with whom he traded, nor did he need to owe a fiduciary duty to the issuer of the securities that were traded. Instead, the misappropriation theory applied when the inside trader violated a fiduciary duty owed

58. Chiarella, 445 U.S. at 240 (Burger, C.J., dissenting).

59. See id. at 236 .

60. 664 F.2d 12 (2d Cir. 1981), rev'd on other grounds by Ingber v. Enzor, 841 F.2d 450 (2d Cir. 1988).

61. See id. at 17.

62. See United States v. Bryan, 58 F.3d 933, 945 (4th Cir. 1995).

63. See SEC v. Switzer, 590 F. Supp. 756, 766 (W.D. Okla. 1984) (stating that it is not unlawful to trade on the basis of inadvertently overheard information). 
to the source of the information. ${ }^{64}$ Had the misappropriation theory been available against Chiarella, for example, his conviction could have been upheld even though he owed no duties to those with whom he had traded. Instead, the breach of the duty he owed to Pandick Press would have sufficed.

The misappropriation theory should be seen as the vehicle by which the SEC sought to recapture as much as possible the ground it had lost in Chiarella and Dirks. In the years before O'Hagan, the SEC (and the lower courts) seemed to view the fiduciary duty element as a mere inconvenience that should not stand in the way of expansive insider trading liability. They consistently sought to evade the spirit of the fiduciary duty requirement, while complying with its letter. Even a former SEC Commissioner admitted as much, acknowledging that the misappropriation theory was "merely a pretext for enforcing equal opportunity in information." 65 In terms of the road parable, the SEC used the misappropriation theory as a means of curving the prohibition back towards the direction in which Texas Gulf Sulphur had initially set it.

As with other significant turns in the prohibition's evolutionary path, the SEC's support for the misappropriation theory was likely not accidental. ${ }^{66}$ During the 1980 s, the Commission embarked upon a limited program of deregulating the securities markets. Among other things, it adopted a safe harbor for projections and other soft data, the shelf registration rule, and the integrated disclosure system, as well as expanded the exemptions from registration under the Securities Act. The deregulatory trend motivated one long-time critic of the SEC to compliment the Commission for being "well on the road toward a sensible disclosure system with much of the dead wood, idiosyncrasies, overregulation, and overdrafting eliminated."67 At about the same time, however, the SEC adopted a vigorous enforcement campaign against insider trading. Not only did the number of cases increase substantially, but also the Commission adopted a "big bang" approach under which it focused on high visibility cases that would produce substantial publicity. In part, this may have been due to an increase in the frequency of insider trading, but one suspects the Commission's renewed interest in insider trading was motivated in large measure by a desire to preserve its budget during an era of deregulation and spending restraint. By virtue of the misappropriation

64. See e.g., United States v. Carpenter, 791 F.2d 1024, 1028-29 (2d Cir. 1986), (applying misappropriation theory to a journalist who breaches his duty of confidentiality to his employer).

65. Charles C. Cox \& Keven S. Fogarty, Bases of Insider Trading Law, 49 Oнго ST. L.J. 353, 366 (1988).

66. Again, I have offered a more elaborate version of this argument elsewhere, upon which the following discussion draws. See Bainbridge, State Law, supra note 24, at 1246-51. The argument there is built, inter alia, on Michael P. DOoley, Fundamentals of CORPORATE LAW 816-57 (1995); JoNATHAN R. MACEY, INSIDER TRADING: ECONOMICS, POLITICS, AND POLICY (1991).

67. Homer Kripke, Has the SEC Taken All the Dead Wood Out of Its Disclosure System?, 39 Bus. LAw. 833, 833 (1983). 
theory, the Commission restored much of the prohibition's pre-Chiarella breadth, and thereby ensured that its budget-justifying enforcement program would continue unimpeded.

Moreover, this point in its evolution, the insider trading prohibition had come to benefit important interest groups. Again, the road parable provides a useful analogy. In its early years, a proposal to straighten the road would perhaps have faced little opposition. Today, however, buildings have sprung up along its present course. The road could not be straightened without tearing down some buildings, and perhaps leaving other landowners without an ingress and egress. Local interests with settled expectations thus might strenuously oppose any major redirection of the road.

Just so with the insider trading prohibition. The post-Chiarella insider trading rules have been supported and driven in large part by market professionals, a cohesive and politically powerful interest group, which the post-Chiarella regime effectively insulates from insider trading liability. Only insiders and quasi-insiders, such as lawyers and investment bankers, have a greater degree of access to nonpublic information that might affect a firm's stock price than market professionals. By basing insider trading liability on breach of fiduciary duty, and positing that the requisite fiduciary duty exists with respect to insiders and quasi-insiders but not with respect to market professionals, the prohibition protects the latter's ability to profit from new information about a firm.

\section{Regrettable Choices}

In the road parable, path dependence has economic significance only if today's authorities have reason to regret the choices their predecessors made. Likewise, as we ponder the insider trading prohibition's S-curve, should policymakers regret its evolutionary path? In my judgment, the securities fraud path was a problematic choice.

Securities fraud traditionally has been concerned with protection of investors and preservation of investor confidence in the integrity of the securities markets. ${ }^{68}$ Whether insider trading implicates those policies is highly controverted. My own view, which I have set forth in detail elsewhere, is that, as a general matter, insider trading neither harms investors nor undermines their confidence in the markets. ${ }^{69}$ Assuming arguendo the relevance of those policies to insider trading, however, the prohibition's present shape seems anomalous.

Under current law, investors' rights vary widely depending on the identity of the trader, the nature of the inside information, and the source of that information. Consider United States v. Carpenter. ${ }^{70}$ R. Foster Wi-

68. See, e.g., Central Bank v. First Interstate Bank, 511 U.S. 164, 173-74 (1994) (stating that the SEC argues "the broad congressional purposes behind the [securities laws are] to protect investors from false and misleading practices that might injure them ....").

69. See Bainbridge, State Law, supra note 24, at 1238-43.

70. 791 F.2d 1024 (2d Cir. 1986). 
nans wrote the Wall Street Journal's "Heard on the Street" column, a daily report on various stocks that is said to affect the price of the stocks discussed. Journal policy expressly treated the column's contents prior to publication as confidential information belonging to the newspaper. Despite that rule, Winans agreed to provide several co-conspirators with prepublication information as to the timing and contents of future columns. His fellow conspirators then traded in those stocks based on the expected impact of the column on the stocks' prices, sharing the profits.

Any duties Winans owed in this situation ran to an entity that had neither issued the securities in question nor even participated in stock market transactions. It is not immediately apparent what Winans's breach of his duties to the Wall Street Journal has to do with the federal securities laws. The incongruity of the misappropriation theory becomes even more apparent when one considers that its logic suggests that the Wall Street Journal could lawfully trade on the same information used by Winans. If we are really concerned with protecting investors and maintaining their confidence in the market's integrity, the inside trader's identity ought to be irrelevant. As Texas Gulf Sulphur recognized, from the investor's point of view, insider trading is a matter of concern because they have traded with someone with superior access to information. From the investor's perspective, it does not matter whether it is Winans or the Journal on the opposite side of the transaction. Both have greater access to the relevant information than do investors.

The logic of the misappropriation theory also suggests that Winans would not have been liable if the Wall Street Journal had authorized his trades. In that instance, his trades would not have constituted an improper conversion of nonpublic information, and the essential breach of fiduciary duty would not be present. Again, however, from an investor's perspective, it would not seem to matter whether Winans's trades were authorized or not.

Finally, conduct that is lawful under the misappropriation theory is clearly proscribed by Rule $14 \mathrm{e}-3 .{ }^{71}$ For example, a takeover bidder may not authorize others to trade on information about a pending tender offer even though such trading might aid the bidder by putting stock in friendly hands. If the acquisition is to take place by means other than a tender offer, however, Rule 14e-3 will not apply, and neither should the misappropriation theory. From an investor's perspective, however, the form of the acquisition seems just as irrelevant as the identity of the insider trader.

In sum, if investor protection or confidence in the market were the real issues, one would be hard-pressed to defend the pre-O'Hagan state of the law. An expansive version of the old equal access test seems far better suited to advancing those values, but it (supposedly) expired in Chiarella. Something else must be going on.

71. See 17 C.F.R. § 240.14e-3(c) (1998). 
There is a growing consensus that the federal insider trading prohibition is more easily justified as a means of protecting property rights in information than as a way of protecting investors. ${ }^{72}$ As I have elsewhere defended in some detail, a property rights-based approach to insider trading regulation, ${ }^{73}$ a brief recapitulation will suffice here. Consider the prototypical insider trading transaction, in which an insider trades in her employer's stock on the basis of information learned solely because of her position with the firm. The property right must be assigned to either the corporation or the inside trader. A rule allowing insider trading assigns the property right to the insider, while a rule prohibiting insider trading assigns it to the corporation.

The rationale for assigning the property right to the firm is precisely the same as the rationale for prohibiting patent infringement or theft of trade secrets: protecting the economic incentive to produce socially valuable information. As the theory goes, the readily appropriable nature of information makes it difficult for the developer of a new idea to recoup the sunk costs incurred in developing it. ${ }^{74}$ For example, if an inventor develops a better mousetrap, he cannot profit on that invention without selling mousetraps and thereby making the new design available to potential competitors. Assuming both the inventor and his competitors incur roughly equivalent marginal costs to produce and market the trap, the competitors will be able to set a market price at which the inventor will likely be unable to earn a return on his sunk costs. Ex post, the rational inventor should ignore his sunk costs and go on producing the improved mousetrap. Ex ante, however, the inventor will anticipate that he will be unable to generate positive returns on his up-front costs, and therefore will be deterred from developing socially valuable information. As Judge Ralph Winter explained in his separate opinion in United States $v$. Chestman:

Information is . . . expensive to produce, and, because it involves facts and ideas that can be easily photocopied or carried in one's head, there is a ubiquitous risk that those who pay to produce information will see others reap the profit from it. Where the profit from an activity is likely to be diverted, investment in that activity will decline. If the law fails to protect property rights in commercial in-

72. See Bainbridge, State Law, supra note 24 , at 1252 , n.266. The question for most scholars no longer is whether some form of insider trading regulation is necessary and appropriate to protect property rights in nonpublic information, but whether we should make a federal case of it. See Larry E. Ribstein, Federalism and Insider Trading, 6 SUP. CT. ECON. REv. 123, 171 (1998) ("Misappropriation of information is wrong, but we should not make a federal case out of it."). I take up that question infra notes $145-77$ and accompanying text.

73. See Bainbridge, State Law, supra note 24, at 1252-57. An alternative approach is to ask whether the parties, if they had bargained over the issue, would have assigned the property right to the corporation or the inside trader. See Stephen M. Bainbridge, Insider Trading Under the Restatement of the Law Governing Lawyers, 19 J. CoRP. L. 1, 27-34 (1993).

74. See Robert Cooter \& Thomas Ulen, Law And Economics 119-28 (2d ed. 1997). 
formation, therefore, less will be invested in generating such information. ${ }^{75}$

Accordingly, society provides incentives for inventive activity by using the patent system to give inventors a property right in new ideas. By preventing competitors from appropriating the idea, the patent allows the inventor to charge monopolistic prices for the improved mousetrap, thereby recouping his sunk costs. Trademark, copyright, and trade secret law are all justified on similar grounds.

Granted, this argument may not provide quite as compelling a justification for the insider trading prohibition as it does for the patent system. Legalizing insider trading would likely have a much smaller impact on the corporation's incentive to develop new information than would, say, legalizing patent infringement. It seems plausible, however, that insider trading will have at least some impact on the incentive to produce new information. Again, Judge Winter explains:

[I]nsider trading creates a risk that information will be prematurely disclosed by such trading, and the corporation will lose part or all of its property in that information. Although trades by an insider may rarely affect market price, others who know of the insider's trading may notice that a trader is unusually successful, or simply perceive unusual activity in a stock and guess the information and/or make piggyback trades. A broker who executes a trade for [an insider] may well draw relevant conclusions. Or, as in the instant matter, the trader ... may tell his or her broker about the inside information, who may then trade on his or her account, on clients' accounts, or may tell friends and relatives. One inside trader has publicly attributed his exposure in part to the fact that the bank through which he made trades piggybacked on the trades, as did the broker who made the trades for the bank. Once activity in a stock reaches an unusual stage, others may guess the reason for the trading-the corporate secret. Insider trading thus increases the risk that confidential information acquired at a cost may be disclosed. If so, the owner of the information may lose its investment. ${ }^{76}$

Even if one is skeptical that insider trading poses the sort of threats Winter identifies, the affirmative case for assigning the property right to the corporation is demonstrably stronger than the one for assigning it to the insider, as I have explained elsewhere. ${ }^{77}$ The law, therefore, should assume (although the assumption may sometimes be wrong) that assigning the property right to the firm maximizes the social incentives for the production of valuable new information.

There are essentially two ways of assigning a property right to information: (1) allowing the owner to enter into transactions without disclosing the information; or (2) prohibiting others from using the information. In part).

75. 947 F.2d 551, 576-77 (2d Cir. 1991) (Winter, J., concurring in part and dissenting in

76. Id. at 577-78 (footnote and citations omitted).

77. See Bainbridge, State Law, supra note 24 , at 1255-56. 
effect, the federal insider trading prohibition vests a property right of the latter type in the owner of nonpublic information. To be sure, enforcement of the insider trading prohibition differs rather dramatically from enforcement of, say, trespassing laws. In context, however, the prohibition's enforcement mechanisms are not inconsistent with a property rights analysis. Where public policy argues for giving someone a property right, but the costs of enforcing such a right would be excessive, the state often uses its regulatory powers as a substitute for granting a property right. Insider trading poses such a situation. Private enforcement of the insider trading laws is rare and usually parasitic on public enforcement proceedings. ${ }^{78}$ Indeed, as we shall see below, the very nature of insider trading makes public regulation essential precisely because private enforcement is almost impossible. The insider trading prohibition's regulatory nature thus need not preclude a property rights-based analysis.

Although Judge Winter's Chestman opinion remains the most explicit judicial acceptance of a property rights-based justification for regulating insider trading, there were striking doctrinal parallels between insider trading law pre-O'Hagan and other forms of property rights in information. Using another's trade secret is actionable only if taking the trade secret involved a breach of fiduciary duty, misrepresentation, or theft, for example, which was "an equally apt summary of the law of insider trading after Chiarella and Dirks." 79 In light of such parallels, Winter speculated that the property rights rationale explained both the Supreme Court's decisions in Chiarella and Dirks, as well as the Second Circuit's adoption of the misappropriation theory. 80

Many aspects of the pre-O'Hagan prohibition in fact more consistent with the property rights justification for the prohibition than they were with a securities fraud-based justification. The basic function of a securities fraud regime is to ensure timely disclosure of accurate information to investors. Yet, it seems indisputable that the insider trading prohibition did not lead to increased disclosure. Consider the classic disclose or abstain rule as the Second Circuit pronounced it in Texas Gulf Sulphur; the rule's name was something of a misnomer, of course. The Second Circuit presumably phrased the rule in terms of disclosure because a key element of an omission case under Rule $10 \mathrm{~b}-5$ is that the defendant owed a duty of disclosure to the investor on the other side of the transaction. As a practical matter, however, disclosure was rarely an option. In Texas Gulf Sulphur, for example, the company had no affirmative duty to disclose the ore strike. As the Second Circuit correctly noted, the timing of disclosure was a matter for the business judgment of corporate managers, subject to any affirmative disclosure requirements imposed by the stock exchanges or the SEC. ${ }^{81}$ In this case, moreover, a valuable corporate

78. See Dooley, Enforcement of Insider Trading, supra note 31, at 15-17.

79. Dooley, Fundamentals of Corporate Law, supra note 66, at 776.

80. See United States v. Chestman, 947 F.2d 551, 578 (2d Cir. 1991) (Winter, J., concurring in part and dissenting in part).

81. See Texas Gulf Sulphur Co., 401 F.2d at 851 n.12 (2d Cir.) (1968). 
purpose was served by delaying disclosure: confidentiality prevented competitors from buying up the mineral rights and kept down the price landowners would charge for them. The company, therefore, had no duty to disclose the discovery, at least up until the time that the land acquisition program was completed. Given that the corporation had no duty to disclose, and had decided not to disclose the information, the insiders' fiduciary duties to the corporation precluded them from disclosing it for personal gain. In this case, the company's president had specifically instructed insiders in the know to keep the information confidential, but such an instruction was not technically necessary. Agency law precludes a firm's agents from disclosing confidential information that belongs to their corporate principal, as all information relating to the ore strike clearly did. Disclosure by an insider who wishes to trade, therefore, was only feasible if there was no legitimate corporate purpose for maintaining secrecy. These situations are presumably rare; it is hard to imagine many business developments that can be disclosed immediately without working some harm to the corporation. In most cases, the disclose or abstain rule really does not provide the insider with a disclosure option. Instead, the rule collapses into a rule of abstention. Accordingly, as a former SEC Commissioner admitted, the "insider trading rules probably do not result in more information coming into the market: the 'abstain or disclose' rule for those entrusted with confidential information usually is observed by abstention." $" 82$

It is also telling that many of the prohibition's doctrinal oddities make sense if protection of property rights is the true policy goal. ${ }^{83}$ Consider, for example, the apparent incongruity that Winans could be held liable for trading on information about the Wall Street Journal's "Heard on the Street," but the Journal could have lawfully traded on the same information. As we saw above, this result makes no sense from a traditional securities law perspective. From a property rights perspective, however, the result in Carpenter makes perfect sense: because the information belonged to the Journal, it should be free to use the information as it saw fit, while Winans's use of the same information amounted to a theft of property owned by the Journal.

A property rights-based approach also helps make sense of a couple of aspects of Dirks that are quite puzzling when approached from a securities fraud-based perspective. One is the Court's solicitude for market professionals. After Dirks, market analysts were essentially exempt from

82. Cox \& Fogarty, supra note 65 , at 353 .

83. To be sure, not all aspects of the federal prohibition can be so explained. For example, because property rights generally include some element of transferability, it may seem curious that federal law, at least in some circumstances, does not allow the owner of nonpublic information to authorize others to use it for their own personal gain. See, e.g., 17 C.F.R. \& 240.14e-3(d) (1998) (explaining that a tender offeror may not divulge its takeover plans to anyone likely to trade in target stock). This does not undermine the general validity of the property rights justification. Rather, if protection of property rights is taken as a valid public-regarding policy basis for the prohibition, it gives us a basis for criticizing departures from that norm. 
insider trading liability with respect to nonpublic information they develop because they usually owe no fiduciary duty to the firms they research. Dirks thus essentially assigned the property right to such information to the market analyst rather than to the affected corporation. From a disclosure-oriented perspective, this is puzzling; the analyst and/or his clients will trade on the basis of information other investors lack. From a property perspective, however, the rule is justifiable because it encourages market analysts to expend resources to develop socially valuable information about firms and thereby promote market efficiency. ${ }^{84}$

An even more significant puzzle, which also becomes more easily explicable from a property rights perspective, was the Supreme Court's failure in Chiarella and Dirks to precisely define the basis upon which liability was to be imposed. Did it suffice to show that a fiduciary relationship existed between the inside trader and those with whom she traded (or the source of the information in the case of the misappropriation theory)? Or was it necessary to show that the trade breached a specific fiduciary duty arising out of such a relationship? If the latter, what duty was the relevant one? The Court was never very clear on this issue, but a number of passages in Dirks implied that it was a breach of the fiduciary duty against self-dealing, not merely the existence of a fiduciary relationship or a breach of a duty of confidentiality, that was at issue. The Court, for example, described the elements of an insider trading violation as: "(i) the existence of a relationship affording access to inside information intended to be available only for a corporate purpose, and (ii) the unfairness of allowing a corporate insider to take advantage of that information by trading without disclosure."85 Another passage likewise describes insider trading liability as arising from "the 'inherent unfairness involved where one takes advantage' of 'information intended to be available only for a corporate purpose and not for the personal benefit of anyone." "86 Yet another noted that insiders are "forbidden by their fiduciary relationship from personally using undisclosed corporate information to their advantage." 87 The focus in each instance is on the duty to refrain from selfdealing. From a disclosure oriented approach, in which maximizing disclosure is the principal policy goal, such a focus makes no sense because requiring such a breach limits the class of cases in which disclosure is made. In contrast, from a property rights perspective, these passages make perfect sense, because they focus attention on the basic issue of whether the insider had converted information belonging to the corporation.

While it seems clear that society needs some regulation of insider trading to protect property rights in corporate information, it is not at all clear that securities fraud is the right vehicle for doing so. To the con-

84. See MACEY, supra note 66 , at 21-22.

85. Dirks, 463 U.S. at 653-54 (1983) (quoting Chiarella, 445 U.S. at 227).

86. Id. at 654 (quoting In re Merrill Lynch, 43 S.E.C. 933, 936 (1968)).

87. Dirks, 463 U.S. at 658. 
trary, securities fraud has proven to be a regrettable choice. As both the prohibition and the Supreme Court's general Rule 10b-5 jurisprudence evolved, serious doctrinal tensions between the two emerged.

The federal insider trading prohibition has its statutory basis in Section 10(b) of the Securities Exchange Act of 1934 and SEC Rule 10b-5 thereunder. Both sweep broadly, capturing "any" fraudulent or manipulative conduct "in connection with" the purchase or sale of "any" security. Despite the almost breathtaking expanse of regulatory authority Congress thereby delegated to the Commission, the Supreme Court has "warned against expanding the concept of fraud in the securities context beyond what the words of the Act reasonably will bear."88 As the misappropriation theory came under attack prior to O'Hagan, that warning took on special significance. From a strict textualist perspective, the validity of the misappropriation theory depended upon whether: (1) the deceit, if any, worked by the misappropriator on the source of the information constitutes deception as the term is used in Section 10(b) and Rule 10b-5; and (2) any such deceit is deemed to have occurred "in connection with" the purchase or sale of a security. ${ }^{89}$

In Bryan, the Fourth Circuit defined fraud, as the term is used in Section 10(b) and Rule 10b-5, "as the making of a material misrepresentation or the nondisclosure of material information $\mathrm{n}$ violation of a duty to disclose." 90 So defined, fraud is present in a misappropriation case only in a technical and highly formalistic sense. Although a misappropriator arguably deceives the source of the information, any such deception is really quite inconsequential. The source of the information presumably is injured, if at all, not by the deception, but by the conversion of the information by the misappropriator for his own profit. Hence, it is the breach of fiduciary duty, if any, by the misappropriator that is truly objectionable, while any deception is purely incidental. So understood, the misappropriation theory appears to run afoul of the Supreme Court's holding in Santa Fe that a mere breach of duty cannot give rise to Rule 10b-5 liability. ${ }^{91}$

Santa Fe had attempted to freeze out minority shareholders of one of its subsidiaries by means of a statutory short-form merger. While plaintiff-shareholders had a state law remedy available in the statutory appraisal rights provision, they chose to seek redress under Rule 10b-5 instead. They claimed that the merger violated Rule $10 \mathrm{~b}-5$ because the deal was effected without prior notice to the minority shareholders and

88. United States v. Bryan, 58 F.3d 933, 944 (4th Cir. 1995) (citing Central Bank v. First Interstate Bank, 511 U.S. 164, 174 (1994)).

89. Bryan, 58 F.3d at $944-46$.

90. Id. at 944 .

91. See Santa Fe Industries, Inc. v. Green, 430 U.S. 462 , 476 (1977). See also Bainbridge, State Law, supra note 24, at 1258-61 (discussing the federalism implications of insider trading regulations); Richard W. Painter et al., Don't Ask, Just Tell: Insider Trading after United States v. O'Hagan, 84 VA. L. REv. 153, 174-86 (1998); Ribstein, supra note 72, at 149-54. 
was done without any legitimate business purpose. They also claimed that their shares had been fraudulently under-valued. The Supreme Court held that the plaintiffs had not stated a cause of action under Rule 10b-5.92 The Court opined that Section 10(b) and Rule 10b-5 were only intended to reach deception and manipulation neither of which was present in the case at bar. ${ }^{93}$

Santa $\mathrm{Fe}$ 's requirement that conduct involve deception in order to fall within Rule 10b-5's scope featured prominently in the reasoning of those circuit courts that rejected the misappropriation theory. For example, in Bryan, the Fourth Circuit opined that "the misappropriation theory does not even require deception, but rather allows the imposition of liability upon the mere breach of fiduciary relationship or similar relationship of trust and confidence." 94 As such, the Bryan court conclucled that the theory ran afoul of Santa $\mathrm{Fe} .{ }^{95}$

Of even greater potential relevance to the problem at hand, however, is the Santa Fe Court's concern that a decision in favor of the plaintiffs would result in federalizing much of state corporate law-in many cases overriding well-established state policies of corporate regulation. ${ }^{96}$ In fact, Santa Fe is part of a fairly long line of securities law cases in which the Supreme Court camd down on the states side of federalism disputes. For example, the Court has emphasized that "state regulation of corporate governance is regulation of entities whose very existence and attributes are a product of state law, $" 97$ from which the Court extrapolated the proposition that "[i]t ... is an accepted part of the business landscape in this country for States to create corporations, to prescribe their powers, and to define the rights that are acquired by purchasing their shares." 98 In keeping with that principle, the Court emphasized that state law governs the rights and duties of corporate directors: "[A]s we have said in the past, the first place one must look to determine the powers of corporate directors is in the relevant State's corporation law.... 'Corporations are creatures of state law' ... and it is state law which is the font of corporate directors' powers." 99

92. See Santa Fe, 430 U.S. at 476.

93. See id. at 472.

94. Bryan, 58 F.3d at 948 . This interpretation of the misappropriation theory is clearly incorrect post-O'Hagan, in light of the Supreme Court's clear requirement that the source of the information be deceived, see infra Part IV.A, and arguably misreads the preO'Hagan circuit court decisions endorsing the theory. Although courts adopting the misappropriation theory recognized that Rule 10b-5 only encompasses fraud and manipulation, they held that the deception the misappropriator works on the source of the information sufficed to impose liability on him. See e.g., United States v. Chestman, 947 F.2d 551, 566 (2d Cir. 1991).

95. See Bryan, 58 F.3d at 949.

96. See Santa Fe, 430 U.S. at $478-79$.

97. CTS Corp. v. Dynamics Corp., 481 U.S. 69,89 (1987).

98. Id. at 91. See also id. at 89 ("No principle of corporation law and practice is more firmly established than a State's authority to regulate domestic corporations. ...").

99. Burks v. Lasker, 441 U.S. 471, 478 (1979) (citations omitted). 
The insider trading prohibition co-exists uneasily with these principles. For example, in Santa Fe, the Court held that Rule 10b-5 did not reach claims "in which the essence of the complaint is that shareholders were treated unfairly by a fiduciary." 100 This, however, is the very essence of the complaint made in insider trading cases. The Court also held that extension of Rule 10b-5 to breaches of fiduciary duty was unjustified in light of the state law remedies available to plaintiffs. ${ }^{101}$ Likewise, insider trading plaintiffs have available state law remedies. ${ }^{102}$ Granted, these remedies vary from state to state and are likely to prove unavailing in many cases. The same was true, however, of the state law remedy at issue in Santa Fe. ${ }^{103}$ Finally, the Court expressed reluctance "to federalize the substantial portion of the law of corporations that deals with transactions in securities, particularly where established state policies of corporate regulation would be overridden." 104 But this is precisely what the federal insider trading prohibition did.

Thus, Santa Fe is a serious doctrinal problem for proponents of an insider trading prohibition grounded in securities fraud. The Santa Fe "problem" figured prominently in Bryan's rejection of the misappropriation theory. ${ }^{105}$ Unfortunately, Santa Fe also poses a serious obstacle for those of us favoring a property rights-based justification for the insider trading prohibition. As the Fourth Circuit put it: "the misappropriation theory transforms Section 10(b) from a rule intended to govern and protect relations among market participants who are owed duties under the securities laws into a federal common law governing and protecting any and all trust relationships." 106 This is precisely what a property rights approach mandates, but it also amounts to "the effective federalization of [fiduciary] relationships historically regulated by the states," 107 which is precisely what Santa $\mathrm{Fe}$ was intended to prevent.

Unfortunately, Santa $\mathrm{Fe}$ is not the only doctrinal hurdle that must be overcome. Until quite recently, Rule $10 \mathrm{~b}-5$ was regarded as an example of interstitial lawmaking in which the courts used common-law adjudicatory methods to flesh out the text's bare bones. In Central Bank of Denver, N.A. v. First Interstate Bank, ${ }^{108}$ however, the Supreme Court held that there was no implied private right of action against those who aid and abet violations of Rule 10b-5.109 Central Bank thus substantially limited the scope of secondary liability under the Rule, at least insofar as private party causes of action are concerned. For our purposes, however, the case is more significant for its methodology than its holding. The

100. Santa Fe, 430 U.S. at 477.

101. See id. at 478.

102. See Bainbridge, State Law, supra note 24 , at 1218-27.

103. See id. at 1259.

104. Santa Fe, 430 U.S. at 479.

105. See Bryan, 58 F.3d at $945,948$.

106. Id. at 950 .

107. Id. at 951 .

108. 511 U.S. 164 (1994).

109. See id. at 191 . 
Court held that the scope of conduct prohibited by Section 10(b) (and thus Rule 10b-5) is controlled by the text of the statute. ${ }^{110}$ Where the plain text does not resolve some aspect of the Rule $10 \mathrm{~b}-5$ cause of action, courts must "infer 'how the 1934 Congress would have addressed the issue had the 10b-5 action been included as an express provision of the 1934 Act." "111

Central Bank figured even more prominently than Santa Fe in the reasoning of the Fourth and Eighth Circuit opinions rejecting the misappropriation theory. In O'Hagan, for example, the Eighth Circuit interpreted the statutory prohibition of fraud created by Section 10(b) narrowly to exclude conduct constituting a "mere breach of a fiduciary duty."112 Instead, "the Court [captured] only conduct constituting a material misrepresentation or the nondisclosure of material information in violation of a duty to disclose as statutorily prohibited."113 Because it believed the misappropriation theory permits the imposition of Section 10(b) liability based upon a breach of fiduciary duty without any such deception, the Eighth Circuit held that the theory was inconsistent with the plain statutory text of Section 10(b) and, accordingly, invalid under Central Bank. ${ }^{114}$

The Eighth Circuit further invoked Central Bank to strictly construe the statutory limitation that the requisite deception be committed "in connection with" a securities transaction, ${ }^{115}$ which requirement the court contended the misappropriation theory rendered "nugatory."116 Specifically, the court held that Section 10(b) reaches "only a breach of a duty to parties to the securities transaction or, at the most, to other market participants such as investors."117 Absent such a limitation, the court opined, Section 10(b) would be transformed "into an expansive 'general fraud-on-the-source theory' which seemingly would apply to an infinite number of trust relationships." 118 Such an expansive theory of liability, the court further opined, could not be justified by the text of statute. ${ }^{19}$ In the typical misappropriation case, of course, the source of the information is not the affected purchaser or seller. Often the source is not even a contemporaneous purchaser or seller and frequently has no state in any

110. See id. at 178.

111. Id. at 178 (quoting Musick, Peeler \& Garrett v. Employers Ins.. 508 U.S. 286,294 (1993)). The Court admits this is an "awkward task." Lampf, Pleva, Lipkind, Prupis \& Petigrow v. Gilbertson, 501 U.S. 350, 359 (1991). Justice Scalia put it more colorfully: "We are imagining here." Id. at 366. Central Bank constrained this imaginative process by requiring courts to "use the express causes of action in the securities Acts as the primary model for the $\S 10$ (b) action." Central Bank, 511 U.S. at 178.

112. O'Hagan, 92 F.3d at $617-18$.

113. Id.

114. See id. at 618.

115. Id. at 618 .

116. Id. at 617 .

117. Id. at 618. In Bryan, the Fourth Circuit similarly opined that Section 10(b) is primarily concerned with deception of purchasers and sellers of securities, and at most extends to fraud committed against other persons closely linked to, and with a stake in, a securities transaction. See Bryan, 58 F.3d at 946.

118. O'Hagan, 92 F.3d at 619 (quoting Bryan, 58 F.3d at 950).

119. See O'Hagan, 92 F.3d at 619. 
affected securities transaction. In Carpenter, for example, the Wall Street Journal was neither a purchaser nor a seller of the affected securities, nor did it have a financial stake in any of the affected transactions. ${ }^{120}$ Similarly, in Bryan, the state of West Virginia was neither a purchaser nor seller, and it had no direct stake in Bryan's securities transactions. In neither case did the defendant fail to disclose material information to a market participant to whom he owed a duty of disclosure. Even assuming the misappropriator deceived the source of the information, one must significantly stretch the phrase "in connection with" to bring that fraud within the statute's ambit. As the Fourth Circuit put it: "[t]he misappropriation of information from an individual who is in no way connected to, or even interested in, securities is simply not the kind of conduct with which the securities laws, as presently written, are concerned."121

Much commends the Eighth and Fourth Circuits' interpretation of Section 10(b). The courts carefully considered the Supreme Court's relevant precedents, especially Santa Fe and Central Bank. At least insofar as the misappropriation theory imposes liability solely on the basis of a breach of fiduciary duty to the source of the information, without any requirement that the alleged perpetrator has deceived the persons with whom he traded or other market participants, it ran afoul of those precedents. In contrast, as the Eighth Circuit correctly opined, the lower court decisions endorsing the misappropriation theory generally failed to conduct a rigorous analysis of Section 10(b)'s text or the pertinent Supreme Court decisions. 122

Yet, there were problems applying Central Bank to the insider trading prohibition. Although the Fourth Circuit was careful to opine that Bryan left intact both the disclose or abstain theory of liability and tipping liability thereunder, this was arguably not the case. As we have seen, the duty at issue in tipping cases is not a duty to disclose, but rather a duty to refrain from self-dealing in confidential information owed by the tipper to the source of the information. As such, tipping is subject to the same line of attack invoked by the Bryan court against the misappropriation theory. Even the basic disclose or abstain theory of liability was called into question by Bryan. Granted, insider trading in violation of the disclose or abstain rule involves an element of deception. By definition, the defendant fails to disclose non-public information before trading. The nondisclosure argument, however, is not a very powerful explanation for insider trading liability. Persons subject to the disclose or abstain theory are often also subject to a duty of confidentiality, precluding them from

120. See Carpenter v. United States, 484 U.S. 19, 22 (1987).

121. Bryan, 58 F.3d at 950 .

122. In a telling passage of his partial dissent to a leading Second Circuit opinion endorsing and fleshing out the misappropriation theory, Judge Winter acknowledged that the misappropriation theory lacked "any obvious relationship" to the statutory text of Section 10(b) because "theft rather than fraud or deceit" had become "the gravamen of the prohibition." United States v. Chestman, 947 F.2d 551, 578 (2d Cir. 1991) (Winter, J., concurring in part and dissenting in part). 
disclosing the information. As we have seen, the insider trading prohibition becomes a rule to abstain from trading, rather than a rule requiring disclosure or abstention. In other words, given that the defendant had no right to disclose, it is the failure to abstain from trading, rather than the nondisclosure, which is the basis for imposing liability. The inexorable logic of both Bryan and the Eighth Circuit's O'Hagan opinion called into question not just the misappropriation theory, but the entire federal insider trading prohibition. ${ }^{23}$

A further problem is that the texts provide little guidance as to the scope of insider trading liability. Recall that, under Central Bank, if the text does not resolve some aspect of the Rule 10b-5 cause of action, courts must infer how the 1934 Congress would have addressed the issue if Rule 10b-5 had been included as an express provision of the 1934 Act. ${ }^{124}$ As noted, Central Bank somewhat constrained this imaginative process by requiring courts to use the express causes of action in the securities acts as the primary model for interpreting Rule 10b-5.125 As applied to insider trading, however, this approach is not especially helpful. The short-swing profits cause of action under Section 16(b) of the Exchange Act regulates insider trading only indirectly, does not seek to define insider trading, and does not involve questions of fiduciary duty. Likewise, Section $20 \mathrm{~A}$ provides an express private right of action for insider trading, but was not adopted until more than fifty years after Section 10(b), and moreover, provides no substantive definition of insider trading. Similarly, Section $21 \mathrm{~A}$ creates a treble money civil penalty for insider trading, but suffers from the same flaws as Section $20 \mathrm{~A}$ insofar as it might be used as a source of imaginatively reconstructing congressional intent with respect to Section 10(b).

If we take into account evidence of congressional intent other than the express provisions of the statute, it becomes clear that extending Central Bank to the insider trading context would negate rather than further Congress' intent. There is good evidence that Congress in 1934 did not intend to regulate insider trading in any way other than through the short-swing profit provisions of Section 16(b). ${ }^{126}$ Since 1934, however, Congress has twice amended the Exchange Act for the specific purpose of enhancing the penalties associated with insider trading. ${ }^{127}$ In so doing, it consistently encouraged vigorous SEC enforcement of the federal in-

123. Put another way, the nondisclosure argument is circular. As Chiarella made clear, and Dirks affirmed, not all failures to disclose are fraudulent. Rather, a nondisclosure is actionable only if the trader is subject to a duty to disclose. In turn, a duty to disclose exists only where the trader is subject to a fiduciary duty to refrain from self-dealing in confidential information. Absent such a fiduciary duty, insider trading simply is not fraudulent. Once again, this leaves the disclose or abstain rule subject to the same line of attack adopted by the Fourth and Eighth Circuits.

124. See supra text accompanying note 111.

125. See supra note 111.

126. See Bainbridge, State Law, supra note 24, at 1229-30.

127. See Insider Trading and Securities Fraud Enforcement Act of 1988, Pub. L. No. 100-704, 102 Stat. 4677 (1988); Insider Trading Sanctions Act of 1984, Pub. L. No. 98-376, 98 Stat. 1264 (1984). 
sider trading prohibition. ${ }^{128}$ This sort of ex post facto indication of legislative intent is usually viewed skeptically. In this instance, however, the recent amendments arguably constitute an authoritative congressional endorsement of the insider trading prohibition. ${ }^{129}$

Under the so-called re-enactment doctrine, where Congress revises a statute without reversing prior on-point judicial holdings, that failure has been taken as evidence of congressional approval of those prior holdings. ${ }^{130}$ In adopting neither the 1984 Insider Trading Sanctions Act nor the 1988 Insider Trading and Securities Fraud Enforcement Act, did Congress see fit to reverse either Rule $14 \mathrm{e}-3$ or the misappropriation theory. To the contrary, the legislative history of both acts is replete with statements of congressional approval of those theories. ${ }^{131}$ Indeed, Section 2 of the 1988 Insider Trading and Securities Enforcement Act provides an express congressional finding that the SEC's rules "governing trading while in possession of material, nonpublic information are, as required by such Act, necessary and appropriate in the public interest and for the protection of investors." 132 The accompanying House Report further states that "these findings are intended as an expression of congressional support for these regulations." 133 Moreover, on the substantive level, the 1988 Act overruled Moss v. Morgan, Stanley Inc., ${ }^{134}$ in which the Second Circuit held that private parties lacked standing to sue under the misappropriation theory. The 1988 Act expressly created a private party cause of action for insider trading cases. Because a private party cause of action existed as to all other types of insider trading violations, however, Congress's conduct can only be interpreted as a clear legislative endorsement of the misappropriation theory.

At least insofar as it applies to insider trading cases arising under Rule 10b-5, Central Bank placed the reenactment doctrine in serious jeopardy. The Central Bank majority remarked that arguments based on the reenactment doctrine "deserve little weight in the interpretive process."135 The Court also held that because "Congress has not reenacted the language of $\S 10$ (b) since 1934," it did not need to "determine whether the other conditions for applying the reenactment doctrine are present."136 Hence, even if Congress intended that the 1984 and 1988 amendments expressly endorse the misappropriation theory, Central Bank counsels disregarding that intent. Extension of this aspect of Central Bank to the

128. See e.g., H.R. Rep. No. 100-910 (1988), reprinted in 1998 U.S.C.C.A.N. 6043.

129. For a more exhaustive defense of the proposition that the 1984 and 1988 legislation constitute implicit congressional validation and authorization of both the misappropriation theory and Rule 14e-3, see Steve Thel, Statutory Findings and Insider Trading Regulation, 50 VAND. L. REv. 1091 (1997).

130. See, e.g., Merrill Lynch, Pierce, Fenner \& Smith, Inc. v. Curran, 456 U.S. 353, 378 (1982).

131. See e.g., H.R. Rep. No. 910, supra note 128, at 10, 26; H.R. Rep. No. $98-355$ (1983).

132. Pub. L. No. 100-704, 102 Stat. 4677 (1988).

133. H.R. Rep. No. 910 , supra note 128 , at 35 .

134. 719 F.2d 5, 11 (2d Cir. 1983).

135. Central Bank, 511 U.S. at 187.

136. Id. at 185 . 
insider trading context, however, would be just as problematic as the extension of its main holding. Rejecting the re-enactment doctrine as authority for the misappropriation theory simply because Section 10(b) has never been re-enacted ignores highly relevant congressional action elsewhere in the Act, and thus flouts the apparent congressional intent. If only the intent of the 1934 Congress is relevant, after all, the evidence suggests that Section 10(b) was not concerned with insider trading and the prohibition as a whole should be overturned. This would negate the subsequently adopted statutory penalties for insider trading because there no longer would be any underlying violation to which they could be applied, which is an anomalous result, at best. Should penalties Congress adopted with the clear intent that they be applied to misappropriation of information be rendered nugatory by judicial rejection of the underlying cause of action?

In light of these considerations, reconciling the insider trading prohibition with Central Bank loomed as one of the major doctrinal problems facing the Supreme Court in O'Hagan. It also looms as a major obstacle to a property rights-based understanding of the prohibition. Such an understanding would premise liability on theft, not deception. Because the text of Section 10(b), or Rule 10b-5, clearly addresses deceit, not conversion of intellectual property, the strict textualist approach to statutory interpretation mandated by Central Bank proscribes such an understanding.

\section{E. Starting Over versus Filling Pot Holes}

In the road parable, the city council faces a difficult question. Should it simply repair the road, filling in pot holes and the like, or should it tackle the much harder job of straightening the road? In the former case, users of the road will have to put up with the inefficiencies its curve creates. In the latter case, however, there will be greater expense and potential resistance from adversely affected interest groups (such as owners of land facing the present road or through which the new road would pass).

In United States v. O'Hagan, ${ }^{137}$ the Supreme Court faced a similar dilemma. The Court had previously taken up the misappropriation theory in Carpenter v. United States, ${ }^{138}$ in which a Wall Street Journal reporter and his confederates misappropriated information belonging to the Journal. The Supreme Court upheld the resulting convictions under the mail and wire fraud statutes, holding that confidential business information is property protected by those statutes from being taken by trick, deceit, and chicanery. ${ }^{139}$ As to the defendants' securities fraud convictions, however, the Court split 4-4. Following the long-standing tradition governing evenly divided Supreme Court decisions, ${ }^{140}$ the lower court ruling was

137. 521 U.S. 642 (1997)

138. 484 U.S. 19, 23 (1987).

139. See id. at 28.

140. See Neal v. Biggers, 409 U.S. 188, 192 (1972). 
affirmed without opinion, but that affirmation had no precedential or stare decisis value.

Thus, the way was left open for the Supreme Court to revisit the misappropriation theory in O'Hagan.141 James O'Hagan was a partner in the Minneapolis law firm of Dorsey \& Whitney. In July 1988, Grand Metropolitan PLC ("Grand Met"), retained Dorsey \& Whitney in connection with its planned takeover of Pillsbury Company. Although O'Hagan was not one of the lawyers on the Grand Met project, he learned of their intentions and began buying Pillsbury stock and call options on Pillsbury stock. When Grand Met announced its tender offer in October, the price of Pillsbury stock rose to nearly $\$ 60$ per share. O'Hagan then sold his Pillsbury call options and common stock, making a profit of more than $\$ 4.3$ million. O'Hagan subsequently was indicted and convicted on various charges, the most pertinent for our purposes being that he violated Section 10(b) and Rule $10 \mathrm{~b}-5$ by trading on misappropriated non-public information. ${ }^{142}$ On appeal, the Eighth Circuit reversed O'Hagan's conviction, becoming the second court of appeals (joining the Fourth Circuit) to reject the misappropriation theory. ${ }^{143}$ The Supreme Court granted certiorari to resolve the resulting circuit split.

The Court then had an opportunity to rethink the entire problem. How did the federalism principles of Santa $\mathrm{Fe}$ apply to insider trading? Further, how did statutory interpretation methodology of Central Bank affect insider trading? Like the city council in the road parable, the Court could content itself with patching over the various doctrinal tensions that permeated the misappropriation theory, or it could start over more or less from scratch and erect an entirely new statutory edifice.

Before evaluating what the Supreme Court chose to do, it is useful to further examine the options presented to it. One option was to do away with insider trading regulation in its entirety. Henry Manne's seminal work on insider trading offers a policy justification for this option, ${ }^{144}$ but it does not appear that the Supreme Court ever seriously considered it.

141. United States v. O'Hagan, 521 U.S. 642 (1997).

142. O'Hagan was also indicted for violations of Rule 14e-3, which proscribes insider trading in connection with tender offers, and the federal mail fraud and money laundering statutes. The Eighth Circuit overturned O'Hagan's convictions under those provisions. As to Rule $14 \mathrm{e}-3$, the court held that the SEC lacked authority to adopt a prohibition of insider trading that does not require a breach of fiduciary duty. See O'Hagan, 92 F.3d at 62227. As to O'Hagan's mail fraud and money laundering convictions, the Eighth Circuit also reversed them on grounds that the indictment was structured so as to premise the charges under those provisions on the primary securities fraud violations. See id. at 627-28. Accordingly, in view of the court's reversal of the securities fraud convictions, the latter counts could not stand either. The Supreme Court reversed on all points, reinstating O'Hagan's convictions under all of the statutory violations charged in the indictment. See O'Hagan, 521 U.S. at 678.

143. See O'Hagan, 92 F.3d at 628.

144. See Henry G. Manne, Insider Trading And The Stock Market 163-66 (1966); Henry G. Manne, In Defense of Insider Trading, 44 HARv. Bus. REv., Nov./Dec., 1966, at 113, 120-22; Henry G. Manne, Insider Trading and the Law Professors, 23 VAND. L. Rev. 547, 581 (1970); Henry G. Manne, Insider Trading and Property Rights in New Information, 4 CATO J. 933 (1985). 
In any event, with the emergence of the property rights justification for regulating insider trading, there appears to be little academic support for deregulation today, even in law and economics circles.

Another option recently proposed by Larry Ribstein suggests repealing the federal insider trading prohibition, returning regulatory jurisdiction over to state common law. ${ }^{145}$ Ribstein's analysis begins with a federalism-based argument that the Supreme Court should adopt a basic interpretive principal of limited federal government power. Having done so, the Court "should require a fairly explicit indication of legislative intent as a condition of any significant expansion of federal statute."146 As applied to Rule 10b-5, the Court should strictly interpret the term "deception" to encompass only conduct Congress clearly intended to regulate. ${ }^{147}$ As applied to the problem at hand, Ribstein argues these principles mandate repealing much of the federal insider trading prohibition and returning principal regulatory jurisdiction over insider trading to the states. ${ }^{148}$

I am fully sympathetic with the federalism concerns that motivate this proposal, as a general matter. Indeed, I am largely persuaded by Ribstein's cogent argument that leaving insider trading to the states would be preferable-if we were starting from scratch. It is critical to remember, however, that we do not write on a blank slate here. Texas Gulf Sulphur set us on a path leading away from state corporate law fiduciary duties and towards federal securities fraud law. The resulting evolutionary history cannot be ignored. In a passage of his Chestman opinion, pregnant with path dependence implications, Judge Winter acknowledged that insider trading regulation has little to do with traditional concepts of securities fraud. Nevertheless, he thought it too late to turn back:

It must be noted, however, that, although the [property rights] rationale ... provides a policy for prohibiting a specific kind of insider trading, any obvious relationship to Section $10(\mathrm{~b})$ is presently missing because theft rather than fraud or deceit, seems the gravamen of the prohibition. ... Nevertheless, the law is far enough down this road ... that a court of appeals has no option but to continue the route. ${ }^{149}$

In terms of the road parable, Ribstein is arguing for the most ambitious variant of the project: tearing up the existing road, clearing away the homes and factories that have sprung up along it, and pushing through a new road following a straighter and better path. As the parable suggests, and Judge Winter seems to have recognized, however, doing so is sometimes too costly.

The approach I prefer begins with a recognition that the federal insider trading prohibition is an empty shell, lacking force or substance until it

145. See Ribstein, supra note 72.

146. Id. at 153.

147. Id. at 152 .

148. See id. at 166 ("state law should control").

149. Chestman, 947 F.2d at 578 (Winter, J., dissenting in part). 
has been filled with fiduciary duty concepts. Indeed, it must be so or the analysis becomes wholly circular. Chiarella and Dirks taught that silence was not fraudulent under Rule 10b-5 unless there was a duty to disclose. In turn, the duty to disclose arose when the inside trader had violated a duty arising out of a fiduciary relationship or similar relationship of trust and confidence. If Rule $10 \mathrm{~b}-5$ requires such a duty, but is also the source of the requisite duty, the analysis is circular and meaningless. ${ }^{150}$ Accordingly, the requisite fiduciary duty must come from a source outside Rule $10 \mathrm{~b}-5$ and, indeed, the federal securities laws as a whole.

Development of the requisite duty should be driven by the property rights rationale for regulating insider trading. As we have seen, preO'Hagan law was consistent with the property rights rationale, but had not explicitly adopted it. My proposal mandates an explicit embrace of that rationale. The governing question thus becomes: did the defendant convert nonpublic information belonging to another for personal gain? In rare cases, the defendant may be a complete stranger to the source of the information (one thinks of the scene in Wall Street in which Charlie Sheen's character breaks into an office). In such cases, a Rule 10b-5 disclosure obligation should be imposed if the defendant's conduct violated applicable state laws governing theft of confidential information. In the more usual case, the inside trader and the source of the information are likely to be in a relationship that is arguably fiduciary in character: attorney/client, doctor/patient, employer/employee, etc. In such cases, federal courts should look to state law (specifically the law of the state of incorporation of the issuer) to determine whether a relationship is in fact fiduciary in character, such that the fiduciary is potentially subject to the misappropriation theory, and if so, whether the fiduciary relationship in question includes a duty to refrain from self-dealing in non-public information belonging to the principal.

In my judgment, this approach is superior to one in which all or even a substantial chunk of the responsibility for regulating insider trading is devolved to the states. The affirmative case for devolving responsibility to the states rests on a number of premises with which I am unable to concur. For example, Larry Ribstein's argument rests on an admittedly attractive (at least to me) interpretative principle of limited federal government power. In turn, that principle is derived, inter alia, from a close reading of recent Supreme Court opinions that address the issue of federalism..$^{151}$ One difficulty with this argument is that the federalism issues raised by the misappropriation theory were ably presented to the Supreme Court in O'Hagan by an amicus brief written by law professors Richard Painter, Kim Krawiec, and Cindy Williams. ${ }^{152}$ As we shall see, however, the Court blithely ignored the concerns they identified.

150. See William K. S. Wang \& Marc I. Steinberg, Insider Trading 290-92 (1996).

151. See Ribstein, supra note 72 , at $149-54$.

152. See Brief of Amici Curiae Law Professors and Counsel in Support of Respondent, United States v. O'Hagan, 521 U.S. 642 (1997) (No. 96-842). 
A related problem is that the interpretative principle of limited federal government power allows for a federal insider trading prohibition so long as Congress gives "a fairly explicit indication" that Section 10(b) is intended to reach the conduct in question. ${ }^{153}$ Here Ribstein and I simply disagree as to the import of the 1984 and 1988 insider trading legislation. Ribstein contends that the 1988 legislation provides little support for the misappropriation theory, especially in light of Central Bank's limitations upon the re-enactment doctrine. ${ }^{154}$ As discussed above, I regard the 1984 and 1988 Acts as a strong statement of Congressional support for the misappropriation theory, albeit one that left development of the substantive elements of the theory to the courts.

Finally, the affirmative case for devolution rests in part on the claim that, as laboratories of democracy, states provide heterogeneity, experimentation, and competition. ${ }^{155}$ Heterogeneity and experimentation are desirable, but the power of the path dependence metaphor is its reminder that they do not inexorably lead to efficient outcomes. The fittest do not always survive. State anti-takeover legislation is a widely accepted example of such a case. As the story goes, state competition for corporate charters generally leads to more efficient corporate laws, but interest group pressures and a variety of other market failures led states to adopt inefficient takeover rules. ${ }^{156}$ Query whether insider tracling would not prove another case in which interest group pressures lead to inefficient results? Recall that the political interests that support the modern prohibition are: (1) the SEC's bureaucratic incentives; and (2) market professionals. By a fortuitous happenstance, which illustrates the ways in which path dependent evolution of a legal regime can sometimes lead to desirable outcomes despite dubious starting places, their selfish political interests are potentially reconcilable with a regime focused on protecting property rights in non-public information. Because market professionals are concentrated in a few major financial centers, their influence on the evolution of state common law is likely to be far less pronounced than their influence on the development of federal securities law. As such, state common law is likely to be more responsive in a public choice sense to the interests of local corporate managers than those of distant market professionals.

In any event, once interest groups are introduced into the equation, devolution is exposed as a nonstarter. If politics is the art of the possible, so is law reform. Given the political interests supporting the current prohibition, devolution will remain a theoretical idea at best for the foreseeable future. There is no organized constituency that favors devolution, while strong interest groups would oppose it. Moreover, devolution

153. Ribstein, supra note 72 , at 153 .

154. See id. at 142-43.

155. See id. at 155-57.

156. See, e.g., Frank H. Easterbrook and Daniel R. Fischel, The Economic STRUCTURE OF CORPORATE LAW 218-23 (1991) (describing the benefits of competiton among states for corporate charters). 
would run counter to the institutional interests of the SEC and Congress. Insider trading is still unpopular with the public and with Congress, providing the SEC with political cover for deregulation in other areas and justification for expansive enforcement budgets. Indeed, the misappropriation theory itself bears witness to the SEC's interest in maintaining an expansive insider trading prohibition. ${ }^{157}$

I now turn from a critique of the case for devolution to an affirmative defense of federalizing insider trading regulation. According to the economics of path dependence, the mere fact that the initially chosen starting point is arbitrary or even tainted by self-interest does not necessarily require one to conclude that that assignment was inefficient. Path dependence results in a market failure only if the initial starting point results in inefficient outcomes, and the costs of reversing the initial choice are sufficiently high that the path leading to those outcomes resists correction by market forces. If insider trading is socially undesirable and the SEC is the least cost enforcer, assigning it regulatory authority is defensible, even if the initial assignment was tainted by the agency's self-interest.

I have argued elsewhere that the SEC has a substantial comparative advantage vis-a-vis other potential enforcers of an insider trading prohibition. ${ }^{158}$ To briefly recapitulate, the argument runs as follows: insider trading is hard to detect and difficult to successfully prosecute. Early in my career I estimated that fewer than one in five cases of insider trading is successfully prosecuted, ${ }^{159}$ and in retrospect that estimate is probably too high by several orders of magnitude. It is often very difficult to tell when insider trading is taking place, and even when insider trading is suspected. Further, it is very difficult to identify the responsible party if many people had access to the information.

As a result, the police powers available to the Commission, but not to private parties, ${ }^{160}$ are essential to detecting insider trading. Other duty of loyalty questions, such as usurpation of corporate opportunities and interested director transactions, are appropriately left to private party enforcement under state corporate law because they are both rare and

157. One response to this argument might be that the argument for repeal is directed to courts rather than Congress or the SEC. To be sure, the prohibition is a judicial creation, which courts, in theory, could repeal. Such an argument overlooks the 1984 and 1988 insider trading legislation, which arguably codified the prohibition. At the very least, that legislation suggests judicial repeal of the prohibition would be followed by a Congressional restoration. In any event, it was through the courts-not legislation or rule-making - that the broad insider trading prohibition came into being. As we shall see below, $O$ 'Hagan confirms the on-going judicial support for prohibiting insider trading via Rule 10b-5. See infra Part IV.B.

158. See Bainbridge, State Law, supra note 24 , at 1263-66.

159. See Stephen M. Bainbridge, Note, A Critique of the Insider Trading Sanctions Act of 1984, 71 VA. L. Rev. 455, 489-90 (1985) [hereinafter Bainbridge, A Critique of the Insider Trading Sanctions Act of 1984].

160. Under state corporate law, insider trading was left to private party enforcement. Although state blue sky commissions have some regulatory authority over insider trading, no state agency has vigorously pursued it. As a result, we can concentrate on the choice between private party enforcement and SEC enforcement. 
comparatively easy to detect and prosecute. In a public corporation, opportunities to inside trade are likely to be much more common than are opportunities for self-dealing transactions with the corporation. Insider trading is also easier to hide. Transacting with the corporation necessarily takes place in the open. In contrast, insider trading, which is conducted on impersonal stock exchanges, lends itself to secrecy. Informants, computer monitoring of stock transactions, and reporting of unusual activity by self-regulatory organizations and/or market professionals are the usual ways in which insider trading cases come to light. As a practical matter, these techniques are available only to public law enforcement agencies. In particular, they are most readily available to the SEC.

Unlike private parties, who cannot compel discovery until a non-frivolous case has been filed, the Commission can impound trading records and compel testimony simply because its suspicions are aroused. ${ }^{161}$ As the agency charged with regulating broker-dealers and self-regulatory organizations, the Commission is also uniquely positioned to extract cooperation from securities professionals in conducting investigations. ${ }^{162}$ Finally, the SEC is statutorily authorized to pay bounties to informants, which is particularly important in light of the key role informants played in breaking most of the big insider trading cases of the 1980s. ${ }^{163}$

Internationalization of the securities markets is yet another reason for believing the SEC has a comparative advantage in detecting and prosecuting insider trading. Sophisticated insider trading schemes often make use of off-shore entities or even off-shore markets. The difficulties inherent in extraterritorial investigations and litigation, especially in countries with strong bank secrecy laws, probably would preclude private parties from dealing effectively with insider trading involving off-shore activities. In contrast, the SEC has developed memoranda of understanding with a number of key foreign nations, which provide for reciprocal assistance in prosecuting insider trading and other securities law violations. ${ }^{164}$ The SEC's ability to investigate international insider trading cases was further enhanced by the 1988 Act, which included provisions designed to encourage foreign governments to cooperate with SEC investigations. ${ }^{165}$

Because insider trading is difficult to prosecute, even when detected, allocating prosecutorial responsibility to the SEC may also be justified on institutional expertise grounds. The Commission's enforcement staff will handle many more insider trading cases than will counsel representing private corporations. As such, they will develop greater expertise in handling such prosecutions, which further enhances the Commission's competitive advantage in dealing with insider trading.

161. See Dooley, Enforcement of Insider Trading, supra note 31, at 20.

162. See id.

163. See Stuart J. Kaswell, An Insider's View of the Insider Trading and Securities Fraud Enforcement Act of 1988, 45 Bus. Law. 145, 164-66 (1989).

164. See id. at 172-73.

165. See id. at 171 . 
While acknowledging the SEC's comparative advantage, Ribstein suggested that the SEC could continue its market surveillance function, but turn over misappropriation cases to state regulators and affected private parties. ${ }^{166}$ The idea is an interesting and sophisticated one, but I am not persuaded. Allocating regulatory authority to the SEC brings to bear not only the agency's comparative advantage in detecting insider trading, but also an array of sanctions unavailable to private parties. We know that SEC monitoring detects only a small percentage of insider trading cases. Because the probability of detection is quite low, and the potential gains are quite high, the nominal sanction must be quite high in order to deter insider trading. This is the basic economic rationale behind the draconian penalties imposed on insider trading by the federal securities laws. They combine public law enforcement, which enhances the probability of detection, with onerous criminal and civil sanctions, which increases the nominal sanction. In contrast, the sanction presently available in private party litigation is limited to actual damages or disgorgement of actual profits. While that sanction could be increased, perhaps by creation of the same sort of treble money remedy that exists under the antitrust laws, it may well be the case that criminal sanctions are needed for effective deterrence.

Relying solely on private enforcement may also result in a market for lemons. ${ }^{167}$ Assume there are two groups of investors. One group believes insider trading is adverse to its interests and would prefer to invest in firms that prohibit the practice. Accordingly, this group is willing to pay more for stock issued by companies that adopt policies proscribing insider trading. The other group is willing to allow insider trading by its managers and is not willing to pay more for stock of companies with a policy against insider trading. Unscrupulous corporate management might try to lower the firm's cost of capital by adopting a policy against insider trading, while also getting the benefit of insider trading by failing to vigorously enforce the policy. ${ }^{168}$ Given this potential market for lemons, SEC enforcement of the insider trading prohibition may be KaldorHicks efficient. ${ }^{169}$ Assuming most investors prefer that managers of their

166. See Ribstein, supra note 72 , at 170 .

167. See Frank H. Easterbrook, Insider Trading as an Agency Problem, in PRINCIPALS And Agents: The Structure of Business 81, 89 (John W. Pratt \& Richard J. Zeckhauser eds., 1985).

168. A shareholder could sue derivatively, but such a lawsuit would be unlikely to succeed. Under Delaware law, for example, a suit on the stated facts likely would be a demand required case. See Heineman v. Datapoint Corp., 611 A.2d 950, 952 (Del. 1992) (demand required unless a majority of the board disabled by, inter alia, self-interest). If demand was made and refused, as it likely would be, the business judgment rule would insulate the refusal from review. See Zapata Corp. v. Maldonado, 430 A.2d 779, 784 n.10 (Del. 1981). Unless the board wished to enforce the prohibition, an individual shareholder probably would not be able to do so.

169. To be sure, assuming the market efficiently prices the stock of companies in which managers go unpunished, a market for lemons may not develop. Will the market learn of such failures? Will the market efficiently punish companies that fail to enforce their policies on insider trading? At the very least, proponents of devolution fairly can be asked to bear the burden of proof on these issues. 
firms refrain from insider trading, SEC enforcement relieves them of the costs associated with a regime of private enforcement-namely: (1) identifying which firms have adopted policies against insider trading; and (2) differentiating between firms that credibly promise to enforce those policies and those whose promise is not credible.

A mandatory rule also may be Kaldor-Hicks efficient when viewed from the firm's perspective. Assume there are two groups of firms: one wishes to promise to refrain from insider trading and to provide a credible bond for that promise; the other does not. A mandatory rule backed up by public enforcement and the threat of both criminal and civil sanctions makes the latter group somewhat worse off, but makes the former group considerably better off by making their bond much more credible.

In any case, the notion of creating a regime in which public agencies detect wrongdoing, but then leave enforcement to private parties, strikes me as odd. I suspect such regimes are rare, at best. Instead, where enforcement or other costs are such that private enforcement of property rights is difficult, the law typically uses the state's regulatory powers as a substitute for creating a property right. ${ }^{170}$

Finally, the public choice barriers to devolution also stand as an obstacle to this proposal. The SEC is unlikely to be enthusiastic about the idea, and it seems unlikely that Congress would have much interest in expending federal tax dollars on such a program.

In sum, I remain unconvinced by the affirmative arguments for devolution. Instead, I continue to prefer the approach I advanced several years ago, pursuant to which state law fiduciary duty principles are incorporated into a federal insider trading prohibition. ${ }^{171}$ Doing so provides an exogenous source for the answers to the relevant questions, which obviates the circularity problem that arises if Rule $10 \mathrm{~b}-5$ is the source of those answers. Although it leaves the insider trading problem in federal hands, it somewhat alleviates the resulting federalism tensions by acknowledging a role for state law. Finally, it is a limited and practical reform proposal, which could fly under the radar screen of the interests that support the current federal prohibition.

One objection to incorporating state law fiduciary duties into the federal insider trading prohibition is that doing so will lead to different results on similar facts in different states. In light of this risk some scholars prefer a uniform federal common law of fiduciary obligation. ${ }^{172}$ If the policy justification for regulating insider trading is protection of the property rights of the source of the information, however, there is no justification for developing a uniform federal standard. Instead, the federal government regulates insider trading because the SEC has a comparative advantage over private parties in detecting and deterring insider trading. As already noted, where private enforcement of property rights would be

170. See infra text accompanying notes 173-74.

171. See Bainbridge, State Law, supra note 24.

172. See, e.g., Painter et al., supra note 72 , at 206-07. 
prohibitively costly, we frequently observe state regulation as a substitute. ${ }^{173}$ We see this in the hunting area, for example, where private party enforcement of property rights in wild animals (and to a lesser extent, real property) would be quite costly. Accordingly, hunting regulation substitutes for private property rights. ${ }^{174}$ Given that we are not surprised that hunting regulation varies from state to state, why should we not be equally sanguine about state to state variations in the protections afforded property rights in nonpublic information?

It might also be objected that relying on state law might lead to confusion and forum shopping. But so what? Federalism has costs, one of which is that choice of law issues sometimes result in confusion and/or forum shopping. Alternatively, it might be suggested that questions relating to the definition of conduct regulated by the securities laws should be answered uniformly. But why? Again, it is critical to understand that the federal interest in regulating insider trading is largely a historical accident driven and maintained by agency incentives and interest group pressure. The case for uniformity in this context thus is much weaker than it is where there are legitimate federal interests at stake.

An alternative objection to the idea of incorporating state law principles into the federal prohibition is offered by Larry Ribstein, who contends that states will lack an incentive to develop applicable rules whose sole function is to fill the empty shell at the heart of the federal insider trading prohibition. ${ }^{175}$ Indeed, states arguably lack a vehicle for doing so. I am not persuaded by this objection, however. First, a substantial capital stock of relevant state corporate law already exists. As Ribstein acknowledges, the relevant capital stock includes all state cases dealing with property rights in general and rights in information in particular, as opposed to those dealing with insider trading. ${ }^{176}$ States will still have an incentive and a vehicle to develop that capital stock, despite the existence of a federal insider trading prohibition. Second, while Ribstein is correct that what we are talking about is "the federal courts' version of state law,"177 federal courts are used to developing and applying state common law in diversity cases and the various federal common law contexts into which state law has been incorporated. There is no a priori reason doing so in the insider trading context should prove any more difficult than it has done in those other contexts.

The final and most serious objection to my proposal is that it is inconsistent with both the statutory interpretation methodology mandated by Central Bank and the federalism principles announced in Santa Fe. I concede the point, but offer the following defense: as we have seen, giving those cases their full due would mandate repealing not just the misappro-

173. See Richard A. Posner, Economic Analysis of Law 36 (4th ed. 1992).

174. See id.

175. See Ribstein, supra note 72 , at $169-70$.

176. See id. at 158 .

177. Id. at 170 . 
priation theory, but also the rest of the federal insider trading prohibition. This is politically unattainable and, in view of the SEC's comparative advantages in detecting and deterring insider trading socially undesirable. This is a pragmatic defense for bypassing Central Bank and Santa Fe, but part of the power of the path dependence metaphor is that it provides a rationale for just this sort of pragmatism. ${ }^{178}$ Again, I resort to Judge Winter's cogent observation that "the law is far enough down this road ... that [we have] no option but to continue the route."179

Although a detailed critique of the strict textualism of Central Bank is beyond the scope of this Article, a few comments thereon may be appropriate as further justification for my proposal. In effect, my argument is that the Supreme Court should treat the insider trading prohibition as though it were a species of federal common law. This approach arguably is more consistent with the Supreme Court's traditional approach to Rule 10b-5 than was Central Bank. Justice Rehnquist famously observed that Rule 10b-5 was "a judicial oak which has grown from little more than a legislative acorn." 180 His comment reflects a Rule 10b-5 jurisprudence that was an example of interstitial lawmaking in which the courts used common-law adjudicatory methods to flesh out the bare statutory bones. ${ }^{181}$ The Court routinely said that the starting point for its analysis was the language of the statute, but the Court rarely stopped there. ${ }^{182}$

178. I have elsewhere opined against "excessively pragmatic" statutory interpretation. Stephen M. Bainbridge, Colloquy: Securities Act Section 12(2) After the Gustafson Debacle, 50 Bus. LAw. 1231, 1253 (1995). In Gustafson v. Alloyd Co., 513 U.S. 561 (1995), the Supreme Court substantially restricted the scope of liability under Securities Act, Section 12(a)(2). If the Court had not done so, Section 12(a)(2) might well have displaced Rule $10 \mathrm{~b}-5$ as the principal vehicle for imposition of securities liability. Some commentators have argued that the Supreme Court could appropriately take into account the effect a broad interpretation of Section 12(a)(2) would have on Rule 10b-5 in the course of interpreting the former. See Bainbridge, Securities Act Section 12(2), supra, at 1255, 1257. I argued that "two wrongs don't make a right," contending that the Supreme Court's (arguably) illegitimate creation of the implied right of action should not be used to thereafter justify an incorrect interpretation of an express statutory right of action. Id. at $1256 \mathrm{n} .159$. The core of my argument against Gustafson, however, is that the cart should not be put before the horse: the mere fact that the rule $10 \mathrm{~b}-5$ cause of action is on the books and, Central Bank notwithstanding, is likely to remain there for the foreseeable future, should not control the interpretation of an express statutory provision. See id. at 1255-56. In contrast, the present context involves the quite different question of how courts should interpret the Rule 10b-5 cause of action itself. Notwithstanding my doubts about the legitimacy of the creation of implied private rights of action, fuller explication of which is best left for another day, unless and until the Court overturns the Rule $10 \mathrm{~b}-5$ cause of action, it remains on the books and must be interpreted.

179. Chestman, 947 F.2d at 578 (Winter, J., concurring in part). Interestingly, the Supreme Court itself arguably adopted sub silentio a path dependence approach in Chiarella. Instead of "making an $a b$ initio determination of whether Section $10(\mathrm{~b})$ prohibited insider trading, the [Supreme] Court described the state of the caselaw . . . and impliedly adopted [portions of] that caselaw." Id. at 575.

180. Blue Chip Stamps v. Manor Drug Stores, 421 U.S. 723, 737 (1975).

181. A former SEC solicitor opined that "[m] odern development of the law of insider trading is a classic example of common law in the federal courts. No statute defines insider trading; no statute expressly makes it unlawful." Paul Gonson \& David E. Butler, In Wake of 'Dirks,' Courts Debate Definition of 'Insider', LeGAL Times, Apr. 2, 1984, at 16.

182. See e.g., Pinter v. Dahl, 486 U.S. 622, 650 (1988); Schreiber v. Burlington Northern, Inc., 472 U.S. 1, 8 (1985); Chiarella v. United States, 445 U.S. 222, 226 (1980); Santa Fe 
Instead, the Court also looked to legislative history and to judicial and administrative interpretations of the relevant provisions. In other words, the Court engaged in an interpretative process little different from common law adjudication. As Judge Winter explained, the text of Section 10(b) can be seen as "a general authorization to the SEC and to the courts to fashion rules founded largely on those tribunals' judgments as to why insider trading is or is not fraudulent, deceptive, or manipulative." 183 As we have seen, such an approach appears to be consistent with congressional intent as expressed by the 1984 and 1988 insider trading statutes, which left the task of defining insider trading to the courts. In effect, those statutes renewed Congress's invitation to the courts to develop the insider trading prohibition through a process of common law adjudication. Moreover, as we shall see below, the interpretative methodology (although not the result) applied in O'Hagan is closer to the model I propose than to that espoused in Central Bank. ${ }^{184}$

As to Santa Fe, we have seen that insider trading is qualitatively different from the sorts of breaches of fiduciary duty that opinion protected from being swallowed by Rule 10b-5. It is far more likely a corporation would detect a director who usurped a corporate opportunity, for example, than it is the corporation would detect a director who inside traded on the basis of information belonging to the corporation. Given the SEC's comparative advantage in detecting and deterring insider trading, a pragmatist might well overlook the tension between Santa $\mathrm{Fe}$ and the Chiarella/Dirks framework. In terms of the road parable, the cost of straightening the road (i.e., achieving doctrinal purity) cannot be justified. Patching the potholes may seem preferable, which in this context requires one to accept some doctrinal inconsistencies, while seeking to craft a rule that minimizes them.

Once we get past the Central Bank and Santa Fe hurdles and begin to view the federal insider trading prohibition as a species of federal common law, there is well-established precedent for incorporating state law.

Industries v. Green, 430 U.S. 462, 472 (1977); Ernst \& Ernst v. Hochfelder, 425 U.S. 185, 197 (1976); Blue Chip Stamps v. Manor Drug Stores, 421 U.S. 723, 756 (1975).

183. Chestman, 947 F.2d at 573 (Winter, J., concurring in part).

184. Another way of reconciling my proposal (and the Supreme Court's O'Hagan decision, for that matter) with Central Bank is to focus not on its strict textualist interpretive methodology, but rather its policy implications. Central Bank was one of a series of recent Supreme Court securities law opinions that some observers believe rests on policy of limiting private party litigation under Rule 10b-5. See Bainbridge, Securities Act Section 12(2), supra note 178, at 1254 . If so, the Supreme Court may be more concerned with fidelity to that policy outcome than to any particular interpretive methodology. Such an interpretation of the Supreme Court's recent decisions in this area is buttressed by the parallel implementation of that policy by Congress. The 1995 securities reform legislation and the pending federal preemption legislation, in particular, have been motivated by a quite apparent desire to restrain private party litigation in this area. See id. at 1254 n.153; accord Langevoort, supra note 35, at 887-88. Because insider trading typically does not involve private party litigation, the policy justification underlying Central Bank is inapplicable. The principal difficulty with this argument is that it ascribes a greater degree of fidelity by the court to a specific policy goal than may be plausible. See infra Part IV, B. 
In Burks v. Lasker, ${ }^{185}$ for example, a shareholder of a federally regulated investment company brought suit under the federal securities laws against the company's board of directors. The Supreme Court held that state law controlled the board of directors' ability to use a special litigation committee to terminate the litigation. ${ }^{186}$ As another example, until quite recently, the federal courts applied state statutes of limitation to privateparty lawsuits under Rule 10b-5.187 Although the Supreme Court adopted a unique federal limitations period in Gilbertson, the Court indicated that it would continue to borrow state statutes of limitations in appropriate cases. ${ }^{188}$

The standards for choosing between a uniform federal rule and incorporation of state law on a case-by-case basis are not well-developed, but courts typically consider the impact incorporation of state law would have on the relevant federal statutory policies. In Lampf, for example, the Court created a unique federal statute of limitations for implied federal rights of action because borrowing a state limitations rule would frustrate the purpose of the underlying federal statute. ${ }^{189}$ In Burks, the Court used state law to fill the interstices of a federal statute affecting the powers of directors because doing so did not permit acts prohibited by the federal statute, and was otherwise not inconsistent with the statutory policy. ${ }^{190}$ Thus, the critical question seems to be whether there are important federal interests that would be adversely affected by adopting state law fiduciary duty principles as the federal rule of decision. ${ }^{191}$ Here again, the

185. 441 U.S. 471 (1979).

186. See id. at 486 .

187. See Lampf, Pleva, Lipkind, Prupis \& Petigrow v. Gilbertson, 501 U.S. 350, 354 n.1 (1991) (citing cases).

188. See id. at 355-58. To be sure, while both of these examples involve the use of state common law to fill the interstices of the federal securities laws, and thus suggest that state law could appropriately play a role in insider trading prohibition as well, neither directly addresses the use of state common law to define the elements of a federal claim. This too is possible, however. In DeSylva v. Ballentine, 351 U.S. 570, 580-81 (1956), for example, the Court looked to the state law definition of "children" for purposes of interpreting a federal statute.

189. See Lampf, 501 U.S. at 356.

190. See Burks, 441 U.S. at 479.

191. This interpretation is consistent with the test laid out in the leading case of United States v. Kimbell Foods, Inc., 440 U.S. 715, 728-29 (1979), in which the Supreme Court laid out the following criteria for deciding when state law should be incorporated into federal common law rules:

Undoubtedly, federal programs that "by their nature are and must be uniform in character throughout the Nation" necessitate formulation of controlling federal rules. Conversely, when there is little need for a nationally uniform body of law, state law may be incorporated as the federal rule of decision. Apart from considerations of uniformity, we must also determine whether application of state law would frustrate specific objectives of the federal programs. If so, we must fashion special rules solicitous of those federal interests. Finally, our choice-of-law inquiry must consider the extent to which application of a federal rule would disrupt commercial relationships predicated on state law.

Id. at 728-29 (citations omitted). To be sure, Kimball Foods is not squareiy on point, because the occasion for creating federal common law arose in that case because the United States was a party to the litigation rather than because the claim arose under federal law. 
path dependence metaphor proves useful. Applying it to the problem at hand confirms that the federalization of the insider trading prohibition was a historical accident whose continuation is largely justified by pragmatic concerns of comparative advantage. There is no strong federal interest at stake. As such, there is no need for a uniform federal rule.

It is important to note that while insider trading cases are often brought by the federal government and arise under federal statute, insider trading does not directly affect the rights of, nor threaten to impose liability on the United States. Rather, as the breach of fiduciary duty requirement itself suggests, insider trading mainly implicates private parties' rights and obligations. Courts are more likely to impose uniform national rules in the former case than in the latter. ${ }^{192}$

Incorporating state law into the federal common law of insider trading will further ameliorate the doctrinal tension between Santa Fe and the prohibition. Creating the federal insider trading prohibition involved federalizing an area the states traditionally regulated. Texas Gulf Sulphur easily might have been the first wedge in federalizing the entire body of state corporate law. Santa Fe blunted that threat, but the insider trading prohibition still lingers on the federal stage. By incorporating state law, courts would minimize the extent to which the federal insider trading prohibition intrudes on the state's legitimate zone of regulatory authority over fiduciary duties. Doing so would advance the securities laws federalism policies, without adversely affecting any other policy goals of those laws.

Burks v. Lasker ${ }^{193}$ especially supports this approach. Although the cause of action clearly arose under federal law, the Court applied state law because state law "is the font of corporate directors' powers" and because state law application did not pose a "significant threat to any identifiable federal policy or interest."194 Burks thus strongly argues in favor of using state law to supply the fiduciary duty element of the federal insider trading prohibition. State law is the "font" of corporate fiduciary duties, while state law incorporation poses no threat to "any identifiable federal policy or interest." 195

Although the Supreme Court's decision in DeSylva v. Ballentine ${ }^{196}$ arose outside the securities law area, it is also quite instructive. In that case, the Supreme Court was asked to decide what familial relationships were encompassed by the term "children" as used in a federal statute. The Court looked to state law for the term's definition. It did so in large measure because there was no federal law of domestic relations:

It does confirm, however, the importance of determining whether incorporating state law would adversely affect some federal policy.

192. See, e.g., Miree v. DeKalb County, 433 U.S. 25 (1977).

193. 441 U.S. 471 (1979).

194. Id. at 478-79 (citations omitted).

195. $J d$. at 479 (citations omitted).

196. 351 U.S. 570 (1956). 
The scope of a federal right is, of course, a federal question, but that does not mean that its content is not to be determined by state, rather than federal law. This is especially true where a statute deals with a familial relationship; there is no federal law of domestic relations, which is primarily a matter of state concern. ${ }^{197}$

From this perspective, DeSylva is an especially apt precedent for the insider trading prohibition. Just as there was no general body of federal domestic relations law, Santa Fe teaches that there is no general federal law of fiduciary duty. Just as the Court incorporated state law in $D e$ Sylva, it thus should incorporate state law here.

The lesson of the road parable is that straightening a winding path is not always wise. The securities fraud path upon which Texas Gulf Sulphur put us turned out to be regrettable. It introduced substantial doctrinal tensions that continue to plague the prohibition. Starting over and devolving some or all of the regulatory responsibility to the states, however, would be costly in at least two senses. First, we would lose the benefit of the SEC's comparative advantage in detecting and deterring insider trading. Second, just as straightening the road of the parable would face opposition from the affected landowners, devolution would bump up against strong opposing interests. A more modest approach, such as explicitly incorporating state law fiduciary duty principles into the federal prohibition, alleviates the doctrinal tensions that currently exist (admittedly without solving them) and is less likely to face preclusive opposition from affected interest groups. In terms of the road parable, it is the functional equivalent of patching pot holes, but wise city councils sometimes go that route.

\section{O'HAGAN}

In the road parable, both proponents of straightening the road and proponents of simply patching the pot holes would agree that whatever the city council decides, it should not make the situation worse. Unfortunately, that is more or less what the Supreme Court did in O'Hagan. The Court was presented with an important choice: it could continue down the securities fraud path we had been on since Texas Gulf Sulphur, it could redirect that path in a more explicitly property rights-oriented direction, or it could pursue an entirely different path by eliminating the misappropriation theory or even the prohibition itself. Unfortunately, the Court chose the first option and kept the prohibition in its securities fraud straight-jacket. Worse yet, in doing so it managed to (1) create new and potentially challenging doctrinal problems; (2) exacerbate the doctrinal tensions between the prohibition on the one hand and both Central Bank and Santa Fe on the other; and (3) weaken the protections that the prohibition provides owners of nonpublic information. In most respects, the Court left Rule 10b-5 in a worse state than it found it.

197. Id. at 580 (citations omitted). 


\section{A. The Holding}

The Supreme Court reversed the Eighth Circuit, thereby confirming that the misappropriation theory is a valid basis on which to impose insider trading liability. The majority (per Justice Ginsburg) acknowledged that misappropriators, such as O'Hagan, have no disclosure obligation running to the persons with whom they trade. 198 Instead, it grounded liability under the misappropriation theory on deception of the source of the information. ${ }^{199}$ A fiduciary's undisclosed use of information belonging to his principal, without disclosure of such use to the principal for personal gain, constitutes fraud in connection with the purchase or sale of a security, and thus violates Rule $10 \mathrm{~b}-5$.

Although the Court thus rejected the Fourth and Eighth Circuits' position, the version of the misappropriation theory it endorsed differed from that which the lower courts had crafted. The majority explained that its version of the misappropriation theory addressed the use of "confidential information for securities trading purposes, in breach of a duty owed to the source of the information."200 Accordingly, "a fiduciary's undisclosed, self-serving use of a principal's information to purchase or sell securities, in breach of a duty of loyalty and confidentiality, defrauds the principal of the exclusive use of that information."201 Someone thus can be held liable under this version of the misappropriation theory only where one deceived the source of the information by failing to disclose one's intent to trade on the basis of the information disclosed by the source. This requirement follows, the majority opined, from the statutory requirement that there be a "deceptive device or contrivance" used "in connection with" a securities transaction. ${ }^{202}$ The Supreme Court thus rejected Chief Justice Burger's argument in Chiarella that the misappropriation theory created a disclosure obligation, running to those with whom the misappropriator trades. ${ }^{203}$ Instead, failure to disclose one's intentions to the source of the information constitutes the requisite disclosure violation under the O'Hagan version of the misappropriation theory. ${ }^{204}$

In many respects, $O^{\prime}$ Hagan posed more questions than it answered. Among these are:

1. Liability for brazen misappropriators? The O'Hagan majority made clear that disclosure to the information's source is all that Rule 10b-5 required. If a brazen misappropriator discloses his trading plans to the

198. See O'Hagan, 521 U.S. at 653 n.5. The principal dissent will not go down as one of Justice Thomas' finest moments. It meanders down various inconsequential paths, exploring such momentous questions as whether O'Hagan might have used the information he misappropriated "in a fantasy stock trading game," while ignoring the very serious policy and statutory interpretation questions posed by the misappropriation theory. Id. at 685 .

199. See id. at 653 .

200. Id. at 652 .

201. Id.

202. Id. at 653 .

203. See id. at 655 n.6.

204. See id. at 653-55. 
source, then trades on that information, he does not violate Rule $10 \mathrm{~b}$ 5.205 As we shall see, this is an odd result that jibes with neither the property rights nor the securities fraud rationale for regulating insider trading.

2. Liability for authorized trading? Suppose, for example, a takeover bidder authorized an arbitrageur to trade in the target company's stock on the basis of material nonpublic information about the perspective bidder's intentions. Rule $14 \mathrm{e}-3$ proscribes warehousing of this sort, but only insofar as the information relates to a perspective tender offer. Whether such trading in a non-tender offer context violated Rule 10b-5 was unclear. The O'Hagan majority at least implicitly validated authorized trading of this sort. It approvingly quoted, for example, counsel for the United States' comment that '[t]] satisfy the common law rule that a trustee may not use the property that [has] been entrusted [to] him, there would have to be consent." 206

3. The fiduciary relationship requirement? Does a duty to disclose to the information's source arise before trading in all fiduciary relationships? Consider Model Rule of Professional Conduct 1.8(b), which states: "A lawyer shall not use information relating to representation of a client to the disadvantage of the client unless the client consents after consultation ...."207 Does a lawyer's use of confidential client information for insider trading purposes always operate to the client's disadvantage? If not, and assuming the Model Rule accurately states the lawyer's fiduciary obligation, O'Hagan did not violate Section 10(b). The O'Hagan majority, however, failed to inquire into the nature of O'Hagan's duties, if any, to Grand Met. Instead, the majority assumed that lawyers are fiduciaries, all fiduciaries are subject to a duty to refrain from self-dealing in confidential information, and, accordingly, the misappropriation theory applies to lawyers and all other fiduciaries. The majority's approach, of course, begs the question-is O'Hagan a fiduciary?

4. Criminal or civil? In rejecting the Eighth Circuit's argument that Rule $10 \mathrm{~b}-5$ is primarily concerned with deception of market participants, the majority noted that the discussion in Central Bank, upon which the Eighth Circuit relied, dealt only with private civil litigation under Section

205. See id. at 655 ("[F]ull disclosure forecloses liability under the misappropriation theory: ... . if the fiduciary discloses to the source that he plans to trade on the nonpublic information, there is no 'deceptive device' and thus no $\S 10$ (b) violation ....") Id.

206. Id. at 654 (citations omitted). Footnote 7 to the majority opinion, however, suggests that on these facts O'Hagan would need approval from both Dorsey \& Whitney and Grand Met. See id. at $655 \mathrm{n} .7$. An interesting question is presented by the requirement that O'Hagan disclose his intentions to Dorsey \& Whitney. Given that O'Hagan was a partner in Dorsey \& Whitney, query whether knowledge of his intentions would be imputed to the firm? As a practical matter, of course, O'Hagan should have informed the lawyer with the principal responsibility for the Grand Met transaction and/or the firm's managing partner.

207. Model Rules of Professional Conduct Rule 1.8(b) (1997). 
10(b). ${ }^{208}$ The Court then went on to discuss its holding in Blue Chip Stamps, that only actual purchasers or sellers of securities have standing to bring private causes of action under Rule 10b-5.209 The Court concluded: "Criminal prosecutions do not present the dangers the Court addressed in Blue Chip Stamps, so that decision is 'inapplicable' to indictments for violations of [Section] 10(b) and Rule 10b-5."210 This passage opens the door for misappropriators to argue that $O^{\prime} H a g a n$ should be limited to criminal prosecutions, because the majority acknowledged the limitations imposed by Central Bank and Blue Chip Stamps on private party litigation. Such a limitation on private party litigation, however, seems unlikely. Although the majority declined to address the significance of the 1988 statute and its legislative history for the validity of the misappropriation theory, interpreting O'Hagan as validating the misappropriation theory only as to criminal actions would render the private party cause of action created by Exchange Act Section 20A nugatory.

\section{B. Implications of O'Hagan for the Puzzling Problem of JUDICIAL INCENTIVES}

One of the more puzzling features of the federal insider trading prohibition is the willingness of courts to aid and abet the Commission's efforts. Although the SEC's incentive to erect a broad insider trading prohibition seems easily explainable, it is far less clear why courts would be willing to go along. Yet they have consistently done so. The Cady, Roberts power grab was validated by Texas Gulf Sulphur. The reversal suffered in Chiarella was followed by Newman. The SEC's most recent reversals in O'Hagan and Bryan were just swept aside by the Supreme Court. At every turn, judges have aided and abetted the SEC.

What explains this judicial support for the prohibition? According to a leading judicial behavior theory, "judges seek to impose their personal preferences and values on society." 211 If so, the effort to federalize corporate law becomes easy to understand. First, during the 1960s and '70s, it was conventional wisdom among the legal elites, from which federal judges tend to be selected, that state corporate law was fundamentally flawed. ${ }^{212}$ The tenor of their decisions defining the boundaries between state and federal law reflect this. Second, creating a federal common law of corporations would substantially increase the amount of corporate litigation within the federal court system, giving federal judges many more opportunities to impose their personal views on business corporations. Again, the unpopularity of insider trading and the states' hands-off approach made it a logical candidate for early federalization.

208. See O'Hagan, 521 U.S. at 664.

209. See id. (discussing Blue Chip Stamps v. Manor Drug Stores, 421 U.S. 723 (1975)).

210. Id. at 665 (citations omitted).

211. Richard A. Posner, Economic Analysis of Law 534 (4th ed. 1992).

212. See Stephen M. Bainbridge, Independent Directors and the ALI Corporate Governance Project, 61 Geo. Wash. L. Rev. 1034, 1045 (1993). 
I find this vision of the judicial role unappealing from a normative perspective and unpersuasive from an explanatory perspective. As I have argued elsewhere, judges properly should seek to, and in fact do, enforce not their personal preferences, but rather those policies and moral norms that have substantial support in the community. ${ }^{213}$ Judicial cooperation with the SEC's federalization program, however, is explainable from this perspective as well. In light of the conventional wisdom that state corporate law was seriously flawed and that insider trading was undesirable, judges seeking to faithfully enforce those policy and moral norms having substantial community support would have supported federalizing insider trading law. The lingering effects of the conventional wisdom probably go far in explaining the lower courts' continuing willingness to support an expansive federal insider trading prohibition.

O'Hagan is consistent with this judicial incentives theory, but it also suggests an alternative explanation. There seems to be general agreement that the Supreme Court has not done a very good job in the securities area, especially in recent years. Scholars operating in a wide spectrum of ideological and jurisprudential paradigms have criticized the Court's recent securities opinions. ${ }^{214}$ Supreme Court securities law decisions typically lack a broad, consistent understanding of the relevant public policy considerations. Worse yet, they frequently lack such basics as doctrinal coherence and fidelity to prior opinions. Both points are wellillustrated by the Court's treatment of Central Bank and Santa $\mathrm{Fe}$ in O'Hagan.

Why doesn't the Supreme Court do a better job in securities cases? Bounded rationality provides one answer. Bounded rationality posits that there are inherent limits on the ability of individuals to gather and process information. ${ }^{215}$ Under conditions of uncertainty and complexity, bounded rationality implies that decision makers will not be able to devise a fully specified solution to the problem at hand or fully assess the probable outcomes of their action. ${ }^{216}$

When deciding securities cases, the Court is operating under conditions of complexity and uncertainty. These cases are hard, dry, and highly technical. Supreme Court justices and their clerks arrive on the Court with little expertise in securities law. One assumes that neither the justices nor their clerks have much interest in developing substantial institu-

213. See, e.g., Stephen M. Bainbridge, Social Propositions and Common Law Adjudication, 1990 U. ILL. L. REv. 231 (1990).

214. See, e.g., Bainbridge, Securities Act Section 12(2), supra note 178, at 1232 n.5, 1254 n.153.

215. See generally Oliver E. Williamson, The Economic Institutions of Capitalism: Firms, MARKets, Relational Contracting 30-32, 45-46 (1985) (defining bounded rationality).

216. See Oliver E. Williamson, Markets and Hierarchies: Analysis and AntiTRUST IMPLICATIONS 23 (1975) (under conditions of uncertainty and complexity, it becomes "very costly, perhaps impossible, to describe the complete decision tree."). 
tional expertise in this area after they arrive ${ }^{217}$ (former Justice Powell being the exception that proves the rule). Accordingly, one would be surprised if the Court's securities opinions exhibited anything remotely resembling expert craftsmanship.

This observation is not intended to be pejorative. To the contrary, the justices are acting rationally. Bounded rationality implies that they have a limited ability to master legal information, including the myriad complexities of doctrine and policy in the host of areas annually presented to the Court. Specialization is a rational response to bounded rationalitythe expert in a field makes the most of his limited capacity to absorb and master information by limiting the amount of information that must be processed by limiting the breadth of the field in which he develops expertise. Supreme Court justices will therefore need to specialize, just as experts in other fields. Specializing in securities law would not be rational. The psychic rewards of being a justice-present day celebrity and historical fame-are associated with decisions on the great constitutional issues of the day, not the minutiae of securities regulation.

Under such conditions, one would expect the justices to take securities cases rarely, typically only when there is a serious circuit split, which is in fact what we observe. ${ }^{218}$ When faced with the necessity of deciding securities law issues, the justices and their clerks doubtless recognize that they lack the expertise necessary to decide such questions with confidence. As specialists in a different field, they may be inclined to defer to specialists in the securities law field. ${ }^{219}$ Deference to specialists is a rational response to bounded rationality. Like all decision makers, Supreme Court justices presumably care about their reputation for competence. ${ }^{220} \mathrm{Be}$ cause their decisions are publicly observable, they have a strong incentive to defer to expert opinion. Because even a good decision maker is subject to the proverbial "act of God," the market for reputation evaluates decision makers by looking at both the outcome and the action before forming a judgment. If a bad outcome occurs, but the action was consistent with approved expert opinion, the hit to the decision maker's reputation is reduced. In effect, by deferring to specialists, a decision maker operating under conditions of bounded rationality is buying insurance against a bad outcome.

This model is quite consistent with what happened in O'Hagan. The misappropriation theory was almost two decades old before the Court

217. For an argument that appellate judges routinely duck hard securities law issues, see Mitu Gulati and Catherine McCauliff, On Not Making Law (Sept. 30, 1998) (draft materials on file with author).

218. See Langevoort, supra note 35, at 865 ("[T] $T$ he Supreme Court does extremely little of the adjudicatory work in securities law ....").

219. Cf. William A. Klein, Tailor to the Emperor with No Clothes: The Supreme Court's Tax Rules for Deposits and Advance Payments, 41 UCLA L. Rev. 1685, 1727 (1994) (suggesting that in tax cases the Supreme Court may defer, perhaps even unconsciously, to specialists at the IRS and Treasury).

220. See Gulati and McCauliff, supra note 216 (positing that reputation, prestige, and status are important motivating factors for judges). 
finally resolved its validity. It did so only after a major circuit split had emerged. In resolving the case, the majority did essentially what the government told it to do-the misappropriation section of Justice Ginsburg's opinion repeatedly quoted from or cited to the government's brief and oral argument, almost always approvingly. She framed the case as one involving a "theory of liability for which the Government seeks recognition,"221 and adopted the central element of the government's theory. 222 In other words, she quite blatantly deferred to expert opinion.

More work is necessary to develop a theory of Supreme Court decision making based on specialization and deference to specialists as a response to bounded rationality. One speculates, for example, that justices are more likely to defer to internal rather than external experts. If so, the widely shared assumption that Justice Powell received substantial deference from his colleagues in this area has a rational economic explanation. A future project will attempt to develop the theory in more detail and give it the necessary empirical grounding. At present, the intent is only to be suggestive. Even in its present raw form, however, the theory has identifiable implications for how lower courts should interpret $O$ 'Hagan and other Supreme Court securities opinions.

Consider, for example, the "possession" versus "use" debate. The SEC has long argued that trading while in knowing possession of material nonpublic information satisfies Rule 10b-5's scienter requirement. In United States $v$. Teicher, 223 the Second Circuit agreed, albeit in a passage that appears to be dictum. An attorney tipped stock market speculators about transactions involving clients of his firm. On appeal, the defendants objected to a jury instruction, pursuant to which they could be found guilty of securities fraud, based upon the mere possession of fraudulently obtained material nonpublic information without regard to whether that information was the actual cause of their transactions. The Second Circuit indicated that any error in the instruction was harmless, but went on to opine in favor of a knowing possession test.

In SEC v. Adler, 224 the Eleventh Circuit rejected Teicher in favor of a use standard. ${ }^{225}$ Under Adler:

when an insider trades while in possession of material nonpublic information, a strong inference arises that such information was used by the insider in trading. The insider can attempt to rebut the inference by adducing evidence that there was no causal connection between the information and the trade-i.e., that the information was

221. O'Hagan, 521 U.S. at 654.

222. See id. at 659 .

223. 987 F.2d 112 (2d Cir. 1993).

224. 137 F.3d 1325 (11th Cir. 1998).

225. See id. The Ninth Circuit recently agreed with Adler that Rule $10 \mathrm{~b}-5$ requires proof of use, not mere possession. The Ninth Circuit further held that in criminal cases no presumption of use should be drawn from the fact of possession-the government must affirmatively prove use of nonpublic information. See United States v. Smith, 155 F.3d 1051, 1067-69 (9th Cir. 1998). 
not used. 226

Although defendant Pegram apparently possessed material nonpublic information when he traded, he introduced strong evidence that he had planned to sell company stock, and that his plan predated his acquisition of the information in question. If proven at trial, evidence of such a plan would rebut the inference of use and justify an acquittal on grounds that he lacked the requisite scienter. Similarly, the court opined, evidence that the allegedly illegal trades were consistent with trading would likewise rebut the inference of use. ${ }^{227}$

The choice between Adler and Teicher is difficult. On the one hand, in adopting the Insider Trading Sanctions Act of 1984, Congress imposed treble money civil fines on those who illegally traded "while in possession" of material nonpublic information. ${ }^{228}$ In addition, a use standard significantly complicates the government's burden in insider trading cases. Motivation is always harder to establish than possession, although the inference of use permitted by Adler substantially alleviates this concern. On the other hand, a mere possession test is inconsistent with Rule 10b-5's scienter requirement, which requires fraudulent intent (or at least recklessness). A number of decisions have acknowledged that a pre-existing plan and/or prior trading pattern can be introduced as an affirmative defense in insider trading cases, as such evidence tends to disprove that the defendant acted with the requisite scienter. ${ }^{229}$

The most instructive aspect of Adler and Teicher, for our purposes, is their hermeneutical similarity. Both approach the relevant Supreme Court decisions as an innerrantist approaches Holy Writ. ${ }^{230}$ Both further assume that exegesis at a minute level of Supreme Court opinions in this area is both plausible and practical. In Teicher, for example, the Second Circuit interpreted Chiarella as comporting with "the oft-quoted maxim that one with a fiduciary or similar duty to hold material nonpublic information in confidence must either 'disclose or abstain' with regard to trading."231 In Adler, the Eleventh Circuit carefully parsed language from all three leading Supreme Court opinions, which the court concluded supported the use test. 232 The court at times seems to be reading Supreme Court decisions as though (1) those decisions were statutes to be inter-

226. Adler, $137 \mathrm{~F} .3 \mathrm{~d}$ at 1337.

227. See id. at 1341.

228. For a discussion of the 1984 Act's implications for the possession versus use debate, see Bainbridge, A Critique of the Insider Trading Sanctions Act of 1984, supra note 159, at 493-97.

229. See Adler, 137 F.3d at $1335-36$ (discussing cases).

230. Inerrancy is a theological position most closely associated with evangelical Protestants, who assert that "the Bible in its original autographs and correctly interpreted is entirely true and never false in all it affirms. ..." Evangelical Dictionary of THEOLOGY 142 (Walter A. Ewell ed. 1984).

231. Teicher, 987 F.2d at 120 . The court also favored the possession standard because "[i]t recognizes that one who trades while knowingly possessing material inside information has an informational advantage over other traders." Id. This aspect of the Teicher court's analysis is inconsistent with Chiarella's rejection of the equal access test.

232. See Adler, 137 F.3d at 1333-34, 1338. 
preted from a strict textualist perspective, and (2) one could ascribe intentionality to the justices' utterances. A theory of Supreme Court decision-making that was founded on bounded rationality, by contrast, argues for declining to ascribe intentionality to the Court. Supreme Court decisions in this area should be interpreted narrowly, as reaching only the specific issues before the Court, while dictum should be largely ignored. In other words, the choice between Adler and Teicher should be made almost without reference to the trilogy of Supreme Court insider trading opinions. None of them squarely addresses the issue, and the dictum in each that seems relevant to other issues, such as the possession versus use debate, should get little deference.

\section{Status of Central Bank and Santa Fe}

Another consequence of the infrequency with which the Supreme Court decides securities law issues is that the ballgame typically is not the specific pronouncement the Supreme Court makes a given case, but how that pronouncement is interpreted, extended, and/or restricted by the lower courts. ${ }^{233}$ Lower court judges frequently engage in creative reinterpretation of Supreme Court opinions in this area, as the evolution of the misappropriation theory itself illustrates. ${ }^{234}$ Knowing that the Supreme Court is unlikely to re-visit a particular issue anytime in the near future, if ever, and that the Court's lack of institutional expertise means that it rarely follows its own precedents with fidelity, lower courts feel free to impose their own policy preferences within the often ambiguous guidelines laid down by the Supreme Court. Where the Supreme Court attempts significant shifts in the status quo and/or the direction in which the law is moving, this process of creative reinterpretation frequently leads to a gradual rejection of the new direction and a return to the status quo. ${ }^{235}$ Hence, for example, when Chiarella rejected the equal access standard, lower courts developed the misappropriation theory as a way of restoring much of the prohibition's pre-Chiarella breadth.

This phenomenon readily can be reconciled with path dependence. In terms of the road metaphor, the Supreme Court is not unlike a state or federal highway agency, which knows little about the road's history or the local interests its present shape serves. As a result, one might expect occasional pronouncements that the road must be straightened and generally brought up to agency standards. When local authorities implement these directives, however, their relatively greater expertise and familiarity with relevant local interests may help ensure that the road's present shape remains largely unchanged.

Central Bank and Santa Fe both marked dramatic shifts in the law as it had been developed in lower courts. 236 As a result, both decisions met

233. See Langevoort, supra note 35 , at 865-67.

234. See id. at 866-677.

235. See id. at 867-68.

236. See id. at 886-87. 
with resistance from lower courts. As we have seen, the lower courts that upheld the misappropriation theory ignored Central Bank's negative implications for the theory. Santa $\mathrm{Fe}$ has met with even greater resistance from lower courts. Some courts have permitted $10 \mathrm{~b}-5$ causes of action to lie where the nondisclosure led plaintiffs to forego pursuing an available state law remedy. ${ }^{237}$ This approach has been subjected to well-justified criticism ${ }^{238}$ because it allows litigants to end-run Santa $F e$ by pointing to a nondisclosure or misrepresentation cause of action, even though the bulk of their case goes to breach of fiduciary duty. While it might be argued that liability is being imposed because of the nondisclosure of the breach, rather than because of the breach itself, failure to disclose a breach of duty is not actionable under Rule 10b-5.239 In any case, the lower court approach imposes liability for failing to disclose information not relevant to making investment decisions, which is the concern of the securities laws, but to making state law litigation decisions, a matter wholly outside the scope of securities law. Finally, the lower court's chosen escape device ignores the thrust of Santa Fe by not deferring to the strong policy reasons laid out by the Supreme Court for refraining from intruding federal law into a sphere traditionally left for state law.

The O'Hagan majority gives considerable aid and comfort to those who have sought to limit Central Bank and Santa Fe. The majority essentially orphaned the former. Justice Ginsburg largely ignored the statutory text, except for glib assertions made with respect to the meaning of the phrases "deception" and "in connection with." She likewise ignored the cogent arguments advanced by both the Eighth and Fourth Circuits with respect to the implications of Central Bank for the misappropriation theory. ${ }^{240}$ Most importantly, she ignored the interpretive methodology expounded in Central Bank. ${ }^{241}$ One is therefore left to wonder whether the strict textualist approach taken by Central Bank was an aberrational departure from the more policy-sensitive approach exemplified by previous Supreme Court securities law decisions. ${ }^{242}$

237. See, e.g., Healey v. Catalyst Recovery of Pennsylvania, Inc., 616 F.2d 641 (3d Cir. 1980); Goldberg v. Meridor, 567 F.2d 209 (2d Cir. 1977).

238. See, e.g., Healey, 616 F.2d at 651-61 (Aldisert, J., dissenting).

239. See Biesenbach v. Guenther, 588 F.2d 400, 401 (3d Cir. 1978); In re Sears, Roebuck \& Co. Securities Litig., 792 F. Supp. 977, 981 (E.D. Pa. 1992); Merritt v. Colonial Foods, Inc., 499 F. Supp. 910, 913-14 (D. Del. 1980).

240. To the extent the majority discussed Central Bank's implications for the problem at hand, it focused on dismissing the Eighth Circuit's argument that Central Bank limited Rule 10b-5's regulatory purview to purchasers and sellers. See O'Hagan, 521 U.S. at 664 .

241. Justice Scalia dissented from the majority's Rule 10b-5 holding, relying on the "unelaborated statutory language." Id. at 679.

242. The majority's interpretation of the phrase "in connection with," as used in Section 10(b), is especially troubling. Fraudulent conduct having only a slight connection with a securities transaction is now within the scope of Rule $10 \mathrm{~b}-5$. There has long been a risk that Rule 10b-5 will become a universal solvent, encompassing not only virtually the entire universe of securities fraud, but also much of state corporate law. The minimal contacts $O$ 'Hagan requires between the fraudulent act and a securities transaction substantially exacerbate that risk. The uncertainty created as to Rule $10 \mathrm{~b}-5$ 's parameters fairly raises vagueness and related due process issues, despite the majority's rather glib dismissal of 
As to Santa Fe, Justice Ginsburg correctly described that case as "underscoring that section $10(\mathrm{~b})$ is not an all-purpose breach of fiduciary duty ban; rather it trains on conduct involving manipulation or deception."243 Instead of acknowledging that insider trading is mainly a fiduciary duty issue, however, she treated it solely as a disclosure issue. Thus, failure to disclose that one is about to inside trade is the problem, not the trade itself: "A fiduciary who "[pretends] loyalty to the principal while secretly converting the principal's information for personal gain,' 'dupes' or defrauds the principal."244 As Justice Ginsburg acknowledged, this approach means that full disclosure must preclude liability. ${ }^{245}$

Granted, insider trading involves deception in the sense that the defendant, by definition, failed to disclose nonpublic information before trading. As we have seen, however, persons subject to the disclose or abstain theory are also often subject to a state law-based fiduciary duty of confidentiality, which precludes them from disclosing the information. As to them, the insider trading prohibition becomes a rule to abstain from trading, rather than a rule requiring disclosure or abstention. ${ }^{246}$ Moreover, if such a duty did not exist, identifying the parties to whom the requisite disclosure must be made presents an insurmountable obstacle in cases involving trading on an impersonal stock exchange. As such, $O$ 'Hagan collapses the prohibition into a rule that all fiduciaries must abstain from trading on material nonpublic information. In other words, it really is the failure to abstain from trading, rather than the nondisclosure, which is the basis for imposing liability. The nondisclosure thus remains wholly incidental to the violation, which remains a breach of fiduciary duty. Therefore, Santa Fe remains a serious obstacle for the misappropriation theory.

Justice Ginsburg may or may not have recognized this problem. In either case, her opinion provides a solution, but only at the expense of gutting Santa Fe of its principal meaning. Her majority opinion dismissed Santa Fe as a mere disclosure case: "[I]n Santa Fe Industries, all pertinent facts were disclosed by the persons charged with violating Section 10(b) and Rule 10b-5; therefore, there was no deception through nondisclosure

such concerns. Compare O'Hagan, 521 U.S. at 666 (rejecting O'Hagan's vagueness arguments) with Painter et al., supra note 91, at 196-200 (arguing that the misappropriation theory is impermissibly vague).

243. O'Hagan, 521 U.S. at 655.

244. Id. at 653-54 (citations omitted).

245. See id. at 654 .

246. Justice Ginsburg's approach also can be criticized as reviving the circularity problem discussed above. Recall that failure to disclose material nonpublic information before trading does not always violate Rule $10 \mathrm{~b}-5$. In omission cases, which include all insider trading on impersonal stock exchanges, liability can be imposed only if the defendant had a duty to disclose before trading. If Rule $10 \mathrm{~b}-5$ itself creates the requisite duty, however, this requirement is effectively negated. As such, the requisite duty should come from outside the securities laws. Indeed, given Santa Fe, it must come from outside federal law. Yet, $O$ 'Hagan plausibly can be read as creating a federal disclosure obligation arising out of Rule 10b-5. 
to which liability under those provisions could attach."247 In effect, she endorsed the device by which lower courts have sought to evade Santa Fe. In order to do so, however, she side-lined (by ignoring) the serious federalism concerns that drove Santa Fe.

The conceptual conflict between the Supreme Court's current insider trading jurisprudence and its more general Rule $10 \mathrm{~b}-5$ precedents remains unresolved. Doctrinal purists will find the tensions between the two lines of precedent troubling. If my bounded rationality hypothesis has validity, however, such disparities are not surprising. Indeed, the hypothesis explains the otherwise rather puzzling persistence of the doctrinal tension between the Supreme Court's insider trading cases and the Court's general $10 \mathrm{~b}-5$ jurisprudence. The law may be a seamless web, but as non-specialists dealing with a highly technical field, the justices are unable to see the entire web or predict how tugging on one strand will affect the whole. Again, the problem may be that we err by ascribing intentionality to any Supreme Court precedent in this area. It may be that fidelity to precedent is simply not possible under the conditions we have specified.

The foregoing analysis suggests that the Supreme Court should consciously ask whether deference to specialists is appropriate in a particular instance. Although deference to experts is a rational response by decision makers in the justices' position, such deference may lead them astray when the expert also is a party to an adversarial position. ${ }^{248}$ The govern-

247. O'Hagan, 521 U.S. at 655 (citations omitted).

248. One example of the ways the court can be led astray is offered by the government's contention that agency law supported its position. The government's brief cited sections 388,390, and 395 of the Restatement (Second) of Agency for the proposition that disclosure to the principal is required before the agent may use for personal profit confidential information entrusted to him by the principal. See Weiss, supra note 234, at 426-27 (quoting from and discussing the government's position). In her opinion, Justice Ginsburg cited two of those sections for that very proposition. See O'Hagan, 521 U.S. at 654-55. To be sure, according to the Restatement of Agency, the principal-agent relationship is a fiduciary one with respect to matters within the scope of the agency relationship. See RESTATEMENT (SECOND) OF AGENCY $\& 13$ (1957). More to the point, Section 388 of the Agency Restatement imposes a duty on agents to account for profits made in connection with transactions conducted on the principal's behalf. See id. §388. The comments to that section further expand this duty's scope, requiring the agent to account for any profits made by the use of confidential information even if the principal is not harmed by the agent's use of the information. See id. $\$ 388 \mathrm{cmt}$. c. One can plausibly argue, however, that the apparent bar on insider trading created by agency law is not as strict as it first appears. The broad prohibition of self-dealing in confidential information appears solely in the comments to Sections 388 and 395 . In contrast, the black letter text of Section 388 speaks only of profits made "in connection with transactions conducted by [the agent] on behalf of the principal. ..." Id. \$388. One must stretch the phrases "in connection with" and "on behalf of" pretty far in order to reach insider trading profits. Similarly, Section 395, which speaks directly to the issue of self-dealing in confidential information, only prohibits the use of confidential information for personal gain "in competition with or to the injury of the principal." Id. $\S 395$.. Unless one is confident that insider trading by an agent always injures the principal, agency law thus fails to impose an across-the-board ban on the practice. This argument is supported by Freeman v. Decio, 584 F.2d 186, 191 (7th Cir. 1978) (applying Indiana law) (holding that corporate officers and directors could not be held liable for insider trading as a matter of state corporate law without a showing that the corporation was injured by their conduct). Accord Schein v. Chasen, 313 So. 2 d 739 (Fla. 
ment's interest in O'Hagan was to win, not to clarify the law. As we have seen, the SEC has strong incentives to obtain an expansive insider trading prohibition. Besides that powerful institutional interest, it is important to recall that the government is represented by individual lawyers, for whom winning is itself important. ${ }^{249}$ Unless these lawyers were willing to explicitly make the sort of path dependence-based arguments advanced herein, Central Bank and Santa Fe loomed as serious obstacles to their victory. Therefore, one would not expect them to devote much effort to helping the Court work through the implications of those cases for the misappropriation theory.

\section{O'Hagan and the Property Rights Rationale}

In developing my argument, I have not tried to hide the ball-it should be clear by now that I believe the Supreme Court should have used Judge Winter's opinion in Chestman as a model for deciding O'Hagan. As we have seen, Judge Winter acknowledged that the misappropriation theory lacked any real connection to, or justification under, traditional securities fraud concepts. ${ }^{250}$ Instead, as he also recognized, protection of the source of the information's property rights therein is the strongest justification for a continued prohibition of insider trading. ${ }^{251}$ Using language that smacked of path dependence, Judge Winter opined that technical doctrinal problems posed by the misappropriation theory should be overlooked to preserve the policy benefits the theory provided. 252

The Supreme Court should likewise have treated the prohibition's location in the federal securities laws as a historical accident, which has some continuing justification in the SEC's comparative advantage in detecting and prosecuting insider trading on stock markets. The Court should have then focused on the problem as one of implicating fiduciary duties with respect to property rights in information, rather than one of deceit or manipulation. The Court should have forthrightly acknowledged that this interpretation of the federal insider trading prohibition ran afoul of Central Bank and Santa Fe. Unfortunately, as the Eighth and Fourth Circuit opinions persuasively demonstrated, there does not appear to be any way of preserving the misappropriation theory-and perhaps the prohibition itself-without running afoul of those precedents. As the road parable makes plain, however, there are costs to repairing a path dependent problem. Those costs were (1) doctrinal tensions between two closely related lines of precedent, and (2) the institutional competence of the Supreme Court in making what amounts to federal common law. The Court could

1975). Regarding Section 390 , it is essentially inapplicable to the problem at hand. Section 390 deals with situations in which the agent acts on his own account in transactions with the principal.

249. Klein, supra note 219 , at 1725 n.147 (making the same point with respect to the role of government lawyers in tax cases).

250. See supra text accompanying note 149.

251. See supra text accompanying notes 75-75.

252. See supra text accompanying note 149 . 
have justified incurring those costs by accepting the full implications of Chief Justice Rehnquist's observation that Rule 10b-5 is "a judicial oak which has grown from little more than a legislative acorn."253 In other words, the Court could have treated the insider trading prohibition as a special case of judge-made federal common law, whose continued existence is justified by prudential considerations rather than the precise statutory language of Section $10(\mathrm{~b})$ or doctrinaire federalism.

The majority chose not to do so. Instead, it voluntarily strapped itself into the securities fraud straight-jacket. In doing so, its contribution to resolving the doctrinal tension between the insider trading prohibition and its Central Bank and Santa Fe precedents consisted solely of providing ammunition for those who wish to gut those opinions. Moreover, by preserving the judge-made common law of misappropriation, the Court failed to address the institutional competence questions that continue to plague the prohibition. The majority's approach, in other words, proved no less costly than the approach I have advocated.

The only remaining question is whether the majority did as much damage to the policy basis of the prohibition as it did to the doctrine. As it turns out, the majority opinion is something of a mixed bag. Both proponents and opponents of the property rights rationale will be able to quote passages indicating support for their position, but neither should take much comfort from O'Hagan. The basic problem is that the majority appears to have no clearer understanding of the policy issues at stake than it did of the doctrinal ones.

The majority opinion began promisingly enough with an acknowledgement that confidential information belonging to corporations "qualifies as property." 254 The Court's authorized trading dictum is also consistent with the property rights rationale, while being demonstrably inconsistent with traditional securities law-based policy justifications for the insider trading prohibition. ${ }^{255}$ There is a general presumption that property rights ought to be alienable. Accordingly, if we are concerned with protecting the source of the information's property rights, we generally ought to permit the source to authorize others to trade on that information..$^{256}$ In contrast, legalizing authorized trading makes little sense if the policy goal is the traditional securities fraud concern of protecting investors and

253. Blue Chip Stamps, 421 U.S. at 737.

254. O'Hagan, 521 U.S. at 654.

255. Indeed, one might almost argue that the majority gave too much protection to property rights in information. The logic of the O'Hagan majority suggests that any undisclosed use of a principal's property by an agent constitutes the requisite deception. Suppose, for example, O'Hagan had ordered the shares in question by a long distance telephone call to his broker and billed the call to the firm without its knowledge or consent. (The example is taken from Painter et al., supra note 91, at 178). In such a case, there has been a deception that was consummated when the thief bought securities. As such, the thief-by Justice Ginsburg's logic-has used a deceptive device in connection with the purchase of a security and has violated Rule $10 \mathrm{~b}-5$, which seems patently absurd.

256. See Stephen M. Bainbridge, Insider Trading under the Restatement of the Law Governing Lawyers, 19 J. CORP. L. 1, 37-39 (1993) (noting that mandatory rules may be appropriate in some cases). 
maintaining their confidence in the integrity of the markets. Would an investor who traded with O'Hagan feel any better about doing so if she knew that Dorsey and Whitney had authorized O'Hagan's trades?

The authorized trading dictum has significant, but as yet little-noticed, implications. ${ }^{257}$ Query, for example, whether it applies to all insider trading cases or just to misappropriation cases. Suppose that in a classic disclose or abstain case, such as Texas Gulf Sulphur, the issuer's board of directors adopted a policy that allowed insider trading by managers. If they did so, the corporation has consented to any such inside trading, which under Justice Ginsburg's analysis appears to vitiate any deception. The corporate policy itself presumably would have to be disclosed, just as broad disclosure respecting executive compensation is already required, but the implication is that authorized trading should not result in $10 \mathrm{~b}-5$ liability under either theory. 258

The authorized trading dictum might have even broader implications if its logic is generally extended to Rule $10 \mathrm{~b}-5$. Consider, for example, the dictum's implications for a case like Jordan v. Duff and Phelps, Inc. ${ }^{259}$ which involved a non-insider trading Rule 10b-5 claim which arose out of a merger involving a close corporation. Jordan was a securities analyst who worked for Duff \& Phelps, a credit and securities rating firm. Jordan purchased shares in Duff \& Phelps pursuant to a shareholders agreement that included, inter alia, a mandatory buy-back provision triggered by termination of employment, under which a terminated employee would receive book value for his shares. Unbeknownst to Jordan, Duff \& Phelps was negotiating a merger with Security Pacific. If effected, shareholders would receive a price considerably in excess of book value. Jordan quit, tendered his stock to the company, received the book value thereof, and later learned that Duff \& Phelps was going to be acquired in a leveraged buy-out. Jordan sued under Rule $10 \mathrm{~b}-5$, alleging that the failure to disclose the merger negotiations was an omission of a material fact that the company had a duty to disclose.

The most interesting aspect of the resulting opinion, for our purposes, is the claim made by Judge Posner's dissent: "The terms of the stockholder agreement show that there was no duty of disclosure, and since there was no duty there was no violation of Rule 10b-5."260 In effect, Judge Posner asserted that the scope of the duty to disclose may be defined by contract. Because the shareholder agreement did not require disclosure, there was no duty to disclose. ${ }^{261}$ It is but a short step from

257. I am indebted to my colleague, Mitu Gulati, for suggesting this line of inquiry.

258. Notice that in authorized trading cases this would fall within the misappropriation theory rather than the disclose or abstain rule (i.e., an authorization by the source of market information), so neither the source of the information nor the inside trader would have any obligation to disclose to the market or to those with whom the trader transacts. This observation further illustrates the rather tenuous connection between insider trading and securities fraud.

259. 815 F.2d 429, 431 (7th Cir. 1987).

260. Id. at 444 (Posner, J., dissenting).

261. See id. at $446-47$. 
that holding to the converse proposition that a party to whom a duty to disclose is owed may contractually waive that entitlement. The majority (per Judge Easterbrook) agreed with the principle, but thought it inapplicable on the facts:

It is a violation of duty to steal from the corporate treasury; it is not a violation to write oneself a check that the board has approved as a bonus. We may assume that duties concerning the timing of disclosure by an otherwise-silent firm also may be the subject of contract. Section 29(a) of the Securities Exchange Act of 1934 . . . forbids waivers of the provisions of the Act, and here the critical provision is [Section] 10 (b) ... and the SEC's Rule 10b-5 . . . But a provision must be applicable to be "waived", and the existence of a requirement to speak is a condition of the application of [Section] 10(b) to a person's silence during a securities trade. The obligation to break silence is itself based on state law ... and so may be redefined to the extent state law permits. But we need not decide how far contracts can redefine obligations to disclose. Jordan was an employee at will; he signed no contract. ${ }^{262}$

Jordan stands in sharp contrast with the widely-shared assumption that federal securities laws are mandatory, rather than enabling, and are thus not subject to contractual opting out. ${ }^{263}$ The authorized trading dictum in O'Hagan, however, supports the Easterbrook/Posner position. If mere disclosure of trading intentions suffices to foreclose Rule 10b-5 liability, as Ginsburg states, ${ }^{264}$ then consent to trading must likewise foreclose such liability. If consent to trading on a case-by-case basis forecloses liability, blanket (albeit informed) ex ante consent should do likewise. In neither case has the source of the information been deceived. If ex ante consent would foreclose insider trading liability, the logical implication is that a consensual waiver of a disclosure obligation should also foreclose Rule 10b-5 liability.

I do not propose to delve more deeply into the thorny doctrinal and policy issues raised by this reading of $O^{\prime}$ Hagan. Instead, for my purposes, it suffices to predict that this reading of the majority opinion will not command widespread acceptance. The misappropriation theory announced in O'Hagan is premised on fraud on the source of the information. In Carpenter, for example, liability would be premised on fraud perpetrated on the Wall Street Journal. ${ }^{265}$ Acting through appropriate decision making processes, the Journal could authorize inside trading by its agents. By contrast, however, Chiarella focused the classic disclose or abstain rule on fraud perpetrated on the specific investors with whom the insiders trade. ${ }^{266}$ Authorization of inside trading by the issuer's board of directors, or even by a majority of the shareholders, does not constitute

262. Id. at 436 (citations omitted).

263. See supra text accompanying note 12 .

264. See O'Hagan, 521 U.S. at 655.

265. Cf. id. at 654-55 (noting parallels between Carpenter and misappropriation under Rule 10b-5).

266. See Chiarella, 445 U.S. at 232. 
consent by the specific investors with whom the insider trades. Nothing in O'Hagan explicitly suggests an intent to undermine the Chiarella interpretation of the traditional disclose or abstain rule. To the contrary, Justice Ginsburg expressly states that the two theories are "complementary."267 Because the disclose or abstain rule thus remains conceptually distinct from the misappropriation theory, the authorized trading dictum can be plausibly limited to the latter context.

Institutional analysis of the incentives of the relevant players predicts that the authorized trading dictum decision-makers will seize upon this (or a similar) argument to justify narrowly construing the authorized trading dictum. As we have seen, the SEC has a strong institutional incentive to press for an expansive interpretation of the federal insider trading prohibition. Market professionals and other important interest groups also favor an expansive reading of the prohibition. Lower courts have consistently favored an expansive variant of the prohibition. The status quo bias thus buttresses strong interest group and bureaucratic incentives in favor of an expansive reading. As such, we can expect the SEC to press, and lower courts to accept, a reading of $O$ 'Hagan that proscribes authorized trading in cases covered by the traditional disclose or abstain rule.

Irrespective of whether the foregoing prediction is ratified, the mere fact that the issue arose in the first instance is instructive. Did Justice Ginsburg intend to validate the property rights approach to insider trading? Did Justice Ginsburg intend to validate contractual waivers of Rule 10b-5 duties? I doubt it. The bounded rationality hypothesis advanced above suggests that she probably failed to realize that her dictum had implications reaching beyond the misappropriation context.

Declining to ascribe intentionality to the portions of the majority opinion pointing toward a property rights basis for the prohibition is further justified by the fact that the opinion quickly shifted gears towards treating the problem as one sounding in traditional securities fraud: "Deception through nondisclosure is central to the theory of liability for which the Government seeks recognition," and which the majority accepted. ${ }^{268}$ Indeed, the incoherence of the majority opinion on policy issues is wellillustrated by its arguable revival of the long-discredited equal access theory of liability. ${ }^{269}$ For example, in justifying her claim that the misappropriation theory was consistent with Section 10(b), Justice Ginsburg opined that the theory advances "an animating purpose of the Exchange Act: to insure [sic] honest securities markets and thereby promote investor confidence."270 She went on to claim that "investors likely would hesitate to venture their capital in a market where trading based on mis-

267. See O'Hagan, 521 U.S. at 652.

268. O'Hagan, 521 U.S. at 654.

269. For an argument that O'Hagan is premised on equal access-related concerns, See Weiss, surpa note 234 at 395.

270. O'Hagan, 521 U.S. at 658. 
appropriated nonpublic information is unchecked by law," because those who trade with misappropriators suffer from an informational disadvantage "that cannot be overcome with research or skill."271 The parallels to Texas Gulf Sulphur are obvious. If we want to protect investors from informational disadvantages that cannot be overcome by research or skill, moreover, the equal access test is far better suited to doing so than the ChiarellalDirks framework.

Yet, predictably, the majority showed no greater fidelity to equality of access to information than it did to protection of property rights. In O'Hagan, the majority made clear that disclosure to the source of the information is all that is required under Rule $10 \mathrm{~b}-5$. If a misappropriator brazenly discloses his trading plans to the source, and then trades (either with the source's approval or over its objection), Rule $10 \mathrm{~b}-5$ is not violated. ${ }^{272}$

The brazen misappropriator dictum is inconsistent with both an investor protection rationale for the prohibition and the property rights justification. As to the former, investors who trade with a brazen misappropriator presumably will not feel any greater confidence in the integrity of the securities market if they later find out that the misappropriator had disclosed his intentions to the source of the information. As to the latter, requiring the prospective misappropriator to disclose his intentions before trading provides only weak protection of the source of the information's property rights therein. To be sure, in cases in which the disclosure obligation is satisfied, the difficult task of detecting improper trading is eliminated. Moreover, as the majority pointed out, the source may have state law claims against the misappropriator. ${ }^{273}$ In some jurisdictions, however, it is far from clear whether inside trading by a fiduciary violates state law. ${ }^{274}$ Even where state law proscribes such trading, the Supreme Court's approach means that in brazen misappropriator cases we lose the comparative advantage the SEC has in litigating insider trading cases and the benefit of the well-developed and relatively liberal remedy under Rule $10 \mathrm{~b}-5$.

In sum, the internal inconsistencies that plague the majority opinion preclude any reading of O'Hagan that ascribes rational intentionality thereto. The opinion fails to cohere as to either policy or doctrine. It forecloses neither the equal access nor the property rights policy rationale for the Rule, while also failing to privilege either rationale. As I have demonstrated, this failure is a direct consequence of the Court's failure to appreciate the power of the path dependence metaphor Judge Winter implicitly invoked in Chestman. Just as a child might break his toy by at-

271. Id. at 658-59.

272. See id. at 655 ("full disclosure forecloses liability under the misappropriation theory ... if the fiduciary discloses to the source that he plans to trade on nonpublic information, there is no 'deceptive device' and thus no [Section] 10(b) violation").

273. See id.

274. See Bainbridge, State Law, supra note 24, at 1216-27 (discussing state law on insider trading by corporate counsel, officers, and directors). 
tempting to force a square peg into a round hole, the Supreme Court made a force of insider trading law (and Rule 10b-5 generally) by attempting to force insider trading into securities fraud-a paradigm that does not fit.

\section{CONCLUSION}

O'Hagan represents not just a missed opportunity, but also a serious misstep by the Supreme Court. Neither the majority nor the principal dissent demonstrated any understanding of or concern for the substantial doctrinal and policy issues presented by the case. Neither opinion shed much light on those issues, while the majority in most respects left the field in worse condition than it found it. Santa Fe was gutted, and Central Bank was ignored, but both remain conceptual hurdles for the federal insider trading prohibition. On the policy front, the majority opinion undermined both the property rights and the equal access rationales for regulating insider trading.

What makes O'Hagan so frustrating is that a powerful model for writing a sensible opinion upholding the misappropriation theory lay readily in hand-Judge Winter's Chestman opinion. In this article, I have argued that the colloquial understanding of path dependence offers a heuristically powerful metaphor by which one can grapple with the insider trading problem. The road parable focuses our attention on the proper issues-how did we get to this point, what paths are available for the future, which of those paths are feasible, and what costs would be entailed in choosing one of the various feasible alternatives over the others. This Article posits the following answers to those questions.

- Cady, Roberts, and Texas Gulf Sulphur started the insider trading prohibition down a securities fraud-based evolutionary path. That choice was neither necessary or inevitable, but rather an artifact of the SEC's desire to seize regulatory jurisdiction in order to advance the agency's agenda and interests.

- The securities fraud path proved a regrettable choice. Insider trading is far more closely akin to the class of problems dealt with by state corporate law than that dealt with by federal securities law. As a doctrinal matter, insider trading fits awkwardly, at best, within a fraud model. As a policy matter, regulating insider trading makes sense only as a means of protecting property rights in information, a policy wholly outside the securities laws' purview.

- Yet, as Judge Winter asserted in Chestman, we have gone too far down the federal path to turn back. Settled expectations and interests of both the regulators and the regulated, the status quo bias, and comparative advantages all argue for preserving the prohibition as a species of federal common law.

To be sure, my approach implicates all sorts of issues of institutional competence, statutory interpretation, federalism, and the like, but there is no getting around the fact that the Supreme Court has been creating a federal common law of insider trading-indeed, of securities fraud gener- 
ally-for a very long time. Again, I invoke then-Justice Rehnquist's candid concession that Rule $10 \mathrm{~b}-5$ is "a judicial oak which has grown from little more than a legislative acorn." 275 The Court should again explicitly acknowledge that it is making common law. The rules it announces should be based on protection of property rights, not on inapt securities fraud concepts. Finally, the federalism concerns raised by the conflict between the prohibition and Santa Fe can be finessed by incorporating state law as the rule of decision to the fullest extent possible. This solution is pragmatic and prudential, but since when are they vices rather than virtues?

275. Blue Chip Stamps v. Manor Drug Stores, 421 U.S. 723, 737 (1975). 
[Vol. 52 